\title{
Water Resources and Aquifer Yields in the Charles River Basin, Massachusetts
}

\author{
U.S. Geological Survey
}

Water-Resources Investigations Report 88-4173

Revised 1991

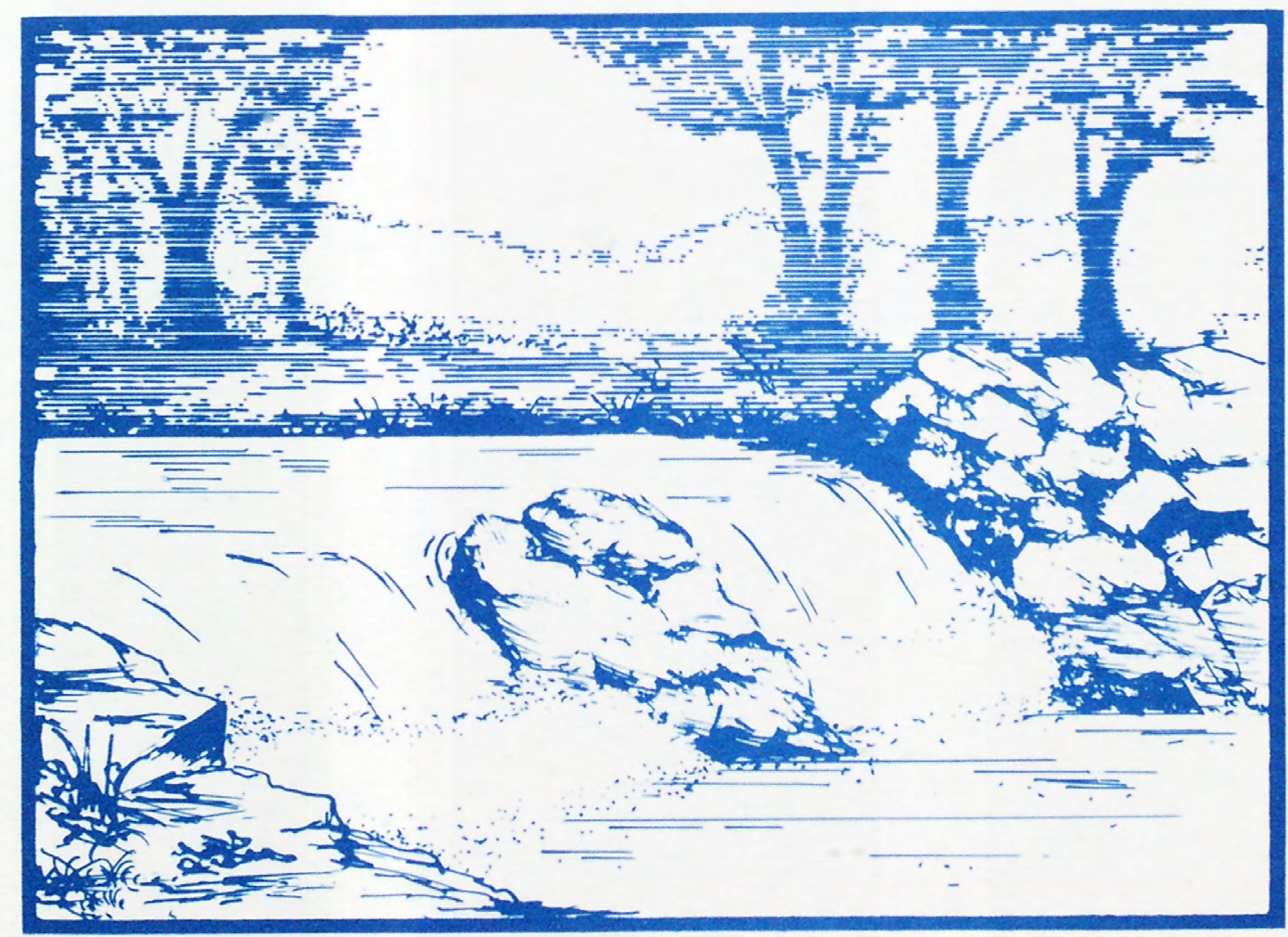

Prepared in cooperation with the

COMMONWEALTH OF MASSACHUSETTS

DEPARTMENT OF ENVIRONMENTAL MANAGEMENT

DIVISION OF WATER RESOURCES 



\section{WATER RESOURCES AND AQUIFER YIELDS IN THE CHARLES RIVER BASIN, MASSACHUSETTS}

By Charles F. Myette and Alison C. Simcox

\section{U.S. GEOLOGICAL SURVEY}

Water-Resources Investigations Report 88-4173

Revised 1991

Prepared in cooperation with the

COMMONWEALTH OF MASSACHUSETTS

DEPARTMENT OF ENVIRONMENTAL MANAGEMENT, DIVISION OF WATER RESOURCES

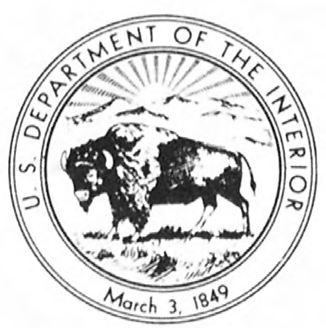

Marlborough, Massachusetts 1992 


\section{U.S. DEPARTMENT OF THE INTERIOR}

MANUEL LUJAN, JR., Secretary

U.S. GEOLOGICAL SURVEY

Dallas L. Peck, Director

For additional information, write to:

District Chief

Massachusetts-Rhode Island District U.S. Geological Survey

Water Resources Division

28 Lord Road, Suite 280

Marlborough, MA 01752
Copies of this report can be purchased from:

U.S. Geological Survey

Books and Open-File Reports Section

Federal Center, Box 25425

Denver, Colorado 80225 


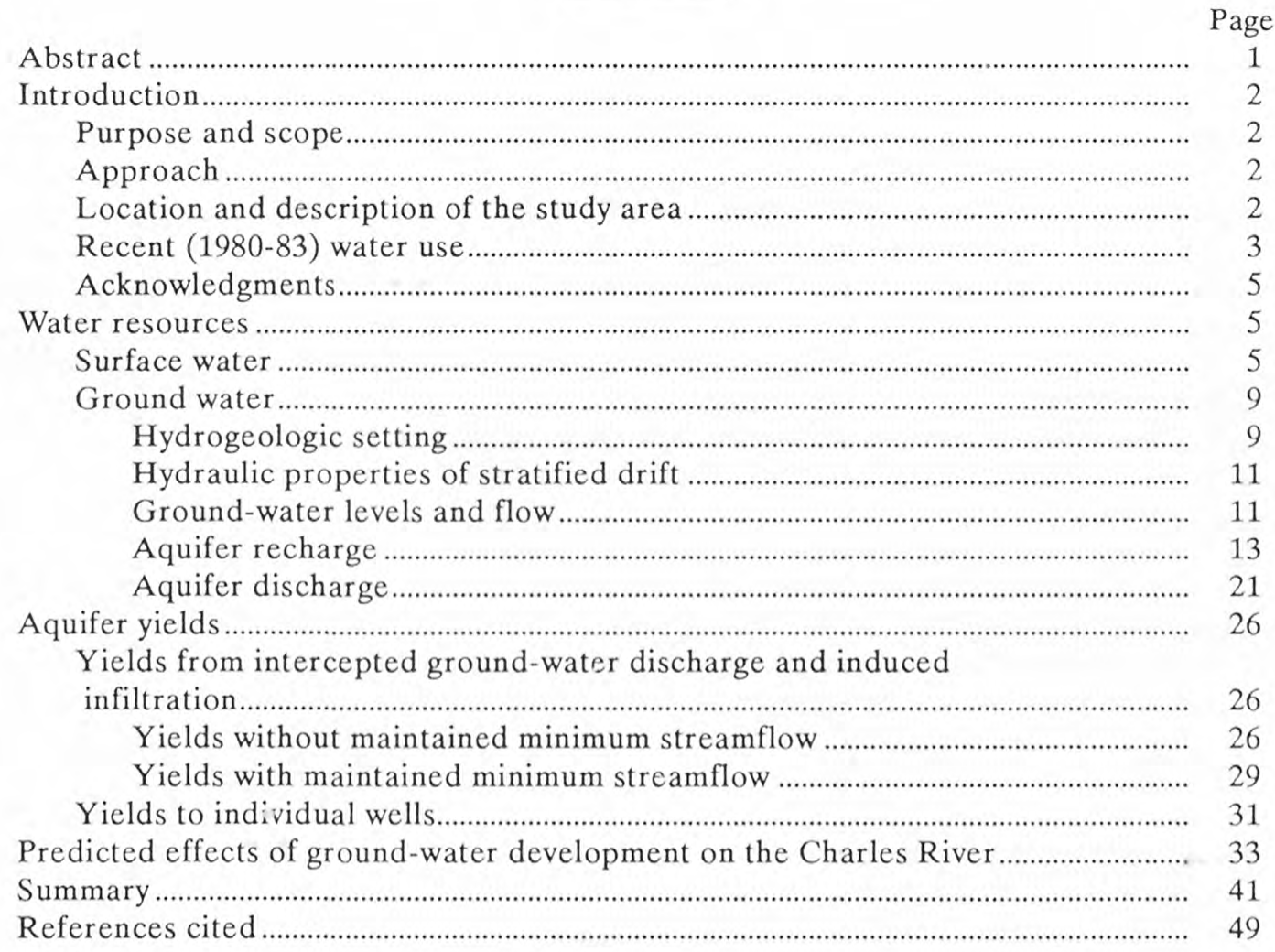

\section{ILLUSTRATIONS}

Figure 1. Map showing location of the study area

2a. Flow-duration curves for the Charles River at U.S. Geological Survey streamflowgaging stations at Dover, water years 1960-83, and at Millis, water years 1975-80 ..

2b. Flow-duration curves for the Charles River at selected U.S. Geological Survey streamflow-gaging stations, water years 1960-83

3. Diagram showing approximate location of tributaries and dams along the Charles River

4-5. Maps showing:

4. Location of the 15 stratified-drift aquifers in the study area .................................... 12

5a. Saturated thickness of the Morse's Pond/Elm Bank aquifer …….............................. 14

5b. Transmissivity of the Morse's Pond/Elm Bank aquifer .............................................. 16

6-8. Graphs showing:

6. Water-level fluctuations in selected wells in eastern Massachusetts, 1965-85

7. Water-level fluctuations in selected wells in stratified-drift aquifers located in and near the Charles River basin, 1965-85

8. Water levels in Dover well DVW-10 in 1984 compared to maximum, minimum, and average monthly water levels in well DVW-10, 1965-84 


\section{ILLUSTRATIONS (continued)}

9. Map showing altitude of the water table in the Morse's Pond/Elm Bank

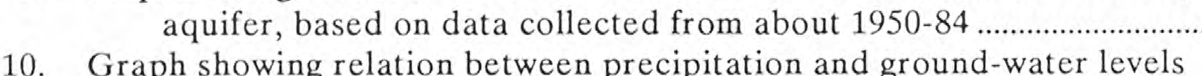
for Dover well DVW-10, 1965-84

10. Graph showing relation between precipitation and ground-water levels

11. Hydrograph from Dover well DVW-10 for 1984 and equation used to determine ground-water recharge

12. Flow-duration curves showing effects of basin geology on streamflow.....

13. Generalized cross section showing the effects of hydrologic and geologic boundaries and well interference on drawdowns of water levels.

14-15. Graphs showing:

14. Theoretical relation between transmissivity, drawdown, and distance from a well at the end of continuous pumping for 30 days at 300 gallons per minute.

15. Theoretical curves for adjustment of drawdown data from figure 15 to compensate for dewatering of a water-table aquifer

16. Nomograph showing theoretical relation between transmissivity, saturated thickness, and maximum yield of wells in stratified-drift aquifers

17. Graph showing observed and simulated streamflow in the Charles River at four U.S. Geological Survey streamflow-gaging stations, 1969-78.

18. Schematic diagram showing location of features simulated in the streamflowaccounting model.

19. Flow chart showing nodes and features simulated in the streamflow-accounting model

20. Graph showing simulated streamflow at the 95-percent flow duration for four U.S. Geological Survey streamflow-gaging stations in the Charles River basin

21. Flow-duration curves of the Charles River at Waltham for ground-water pumpage of $66,77,89$ and 100 million gallons per day.

22. Simulated streamflows at the 95-percent flow duration between southern Natick and Dover

23. Flow-duration curves of the Charles River at Dover resulting from alternative development of the Morse's Pond/Elm Bank aquifer at 4, 7, 10 and 13 million gallons per day.

\section{TABLES}

1. Recent (1980-83) and projected (2000 and 2020) municipal average day demand by towns in the middle and upper Charles River basin and by Cambridge.

2. Low-flow statistics and flow duration of the Charles River and Mother Brook at streamflow-gaging stations near Millis, Dover, Dedham, Wellesley, and Waltham, Mass.

3. Estimated hydraulic conductivity of stratified drift

4. Estimated natural yield from stratified-drift aquifers in the Charles River basin with no maintained minimum streamflow 


\section{TABLES (continued)}

5. Estimated natural and actual yields from stratified-drift aquifers in the

Charles River basin with maintained minimum streamflow

6. Simulated development of water resources in the middle and upper

Charles River basin and effects on streamflow at Waltham.

7. Percentage of time that simulated streamflows in the Charles River at Waltham equaled or exceeded minimum streamflows

8. Simulated development of the Morse's Pond/Elm Bank aquifer and effects on streamflow at Dover

9. Percentage of time that streamflow in the Charles River at Dover equaled or exceeded minimum streamflows 


\section{CONVERSION FACTORS AND VERTICAL DATUM}

\begin{tabular}{lll} 
Multiply & By & To obtain \\
\hline & $\frac{\text { Length }}{25.4}$ & millimeter \\
inch (in.) & 2.54 & centimeter \\
& 0.3048 & meter \\
foot (ft) & 1.609 & kilometer \\
mile (mi) & $\underline{\text { Area }}$ & \\
& 0.09294 & square meter \\
square foot $\left(\mathrm{ft}^{2}\right)$ & 2.590 & square kilometer \\
square mile $\left(\mathrm{mi}^{2}\right)$ & $\underline{\text { Flow }}$ & \\
& 0.02832 & cubic meter per second \\
cubic foot per second $\left(\mathrm{ft}^{3} / \mathrm{s}\right)$ & 0.6462 & million gallons per day \\
& 10.93 & liter per second per square \\
kilometer \\
cubic foot per second per
\end{tabular}

Flow

million gallons per day

per square mile $\left[(\mathrm{Mgal} / \mathrm{d}) / \mathrm{mi}^{2}\right]$

1,460

cubic meter per day

per square kilometer

\section{Hydraulic Conductivity}

foot per day (ft/d)

0.3048

meter per day

\section{$\underline{\text { Transmissivity }}$}

cubic foot per day per square foot times foot of aquifer thickness $\left[\left(\mathrm{ft}^{3} / \mathrm{d}\right) / \mathrm{ft}^{2}\right] \mathrm{ft}$ (reduces to $\mathrm{ft}^{2} / \mathrm{d}$ )

0.09290

cubic meter per day per square meter times meter of aquifer thickness

Sea level: In this report "sea level" refers to the National Geodetic Vertical Datum of 1929 --a geodetic datum derived from a general adjustment of the first-order level nets of the United States and Canada, formerly called Sea Level Datum of 1929. 


\title{
Water Resources and Aquifer Yields in the Charles River Basin, Massachusetts
}

\author{
By Charles F. Myette and Alison C. Simcox
}

\section{ABSTRACT}

In 1984, about $66 \mathrm{Mgal} / \mathrm{d}$ (million gallons per day) of municipally supplied water was used by towns in the middle and upper Charles River basin and by the city of Cambridge in the lower basin. The Division of Water Resources of the Massachusetts Department of Environmental Management estimates that by the year 2020 an additional $11 \mathrm{Mgal} / \mathrm{d}$ of water will be needed to meet demands. The largest sources of unused water in the basin are 15 stratified-drift aquifers along the Charles River that are hydraulically connected to the river and to its major tributaries. These aquifers, which consist mainly of medium to coarse sand and gravel, are generally unconfined, narrow, and discontinuous. They are as much as 100 feet thick, and transmissivity ranges from about 1,000 to 25,000 cubic feet per day per square foot times foot of aquifer thickness. The depth to the water table from the land surface generally is less than 15 feet and the water table fluctuates about 3 to 5 feet annually. Recharge to the aquifers is mostly derived from precipitation, and the aquifers continuously discharge ground water to streams, ponds, lakes, and wetlands.

Aquifer yields from the 15 aquifers under normal climatic conditions were related to the estimated duration of flow of the streams that drain the aquifers. Long-term (180 days or more) aquifer yields that are derived from interception of ground-water discharge range from less than 1 to more than $5 \mathrm{Mgal} / \mathrm{d}$ at the streamflow that is exceeded 95 percent of the time. However, because withdrawal may reduce streamflow in the Charles River to unacceptable levels, these yield estimates were adjusted to meet commonly cited minimum-streamflow criteria. For example, if minimum streamflows in the Charles River are maintained at no less than the annual 7-day, 10-year, mean low flow for 95 percent of the time, only three of the 15 aquifers could sustain yields of more than $1 \mathrm{Mgal} / \mathrm{d}$ from intercepted ground-water discharge. However, none of the aquifers could yield an appreciable amount of water from this source if streamflows are maintained at no less than this minimum for 99 percent of the time.

Yields also are available to wells from water induced by pumping to infiltrate through a streambed. Yields from induced infiltration from the Charles River were estimated for four aquifers and range from about 4 to $11 \mathrm{Mgal} / \mathrm{d}$ at the 95-percent flow duration. If minimum-streamflow criteria are to be maintained, these yield estimates would be substantially lower.

A streamflow-accounting model was used to demonstrate the possible streamflow reductions that could result from further development of the water resources of the middle and upper Charles River basin. Results indicate that pumpage of an additional $11 \mathrm{Mgal} / \mathrm{d}$ could reduce flow in the river at Waltham by about $6 \mathrm{ft}^{3} / \mathrm{s}$ (cubic feet per second) (4 Mgal/d) throughout the year-an amount equal to about 24 percent of the flow that is exceeded 95 percent of the time. Also, model results indicate that increases in pumpage and the export of wastewater from the basin of $23 \mathrm{Mgal} / \mathrm{d}$ would reduce streamflow at Waltham by about $14 \mathrm{ft}^{3} / \mathrm{s}$ ( $9 \mathrm{Mgal} / \mathrm{d}$ ) throughout the year. 
During 1980-83, the average daily use of municipally supplied water by towns in the middle and upper Charles River basin and by the city of Cambridge in the lower basin was about $66 \mathrm{Mgal} / \mathrm{d}$. Of this total, about $50 \mathrm{Mgal} / \mathrm{d}$ flowed out of the basin through the Massachusetts Water Resources Authority (MWRA) sewer system (R. H. Thibedeau, Massachusetts Department of Environmental Management, Division of Water Resources, written commun., 1986). By the year 2020, the Massachusetts Division of Water Resources (MDWR) of the Department of Environmental Management estimates that the use of water in the middle and upper basin and in Cambridge will increase by $11 \mathrm{Mgal} / \mathrm{d}$. The projected increase in demand on the basin's public water-supply systems is based on projected changes in population, service area, per capita use, and industrial and commercial growth. Increased usage of water, coupled with additional development of water resources in the basin and the export of wastewater out of the basin through sewers, may reduce flow in the Charles River to rates that could cause significant water shortages and water quality problems, especially during the summer and fall.

Many reports describe the geology and water resources of the Charles River basin. Bedrock geology of the basin was described by Bell (1948), Dowse (1949), Kaye (1976, 1980), and Volckman (1977); surficial geology was described by Bell (1948), Nelson (1974), Kaye (1976), and Volckman (1975a \& b). Well and boring data, water levels, stream discharges, and chemical data are given in a report by Walker and others (1977). Hydrologic and geologic data are given on maps and diagrams in a U.S. Geological Survey Hydrologic Investigations Atlas compiled by Walker and others (1975). Studies of the quality of the Charles River were completed by the U.S. Federal Water Pollution Administration (1968), the U.S. Environmental Protection Agency (1971), and the Massachusetts Department of Environmental Quality Engineering (1976, 1977, 1979). More than 30 reports by private consultants and State universities describe aspects of the water resources of towns in the Charles River basin.

The study reported here, a cooperative effort by the U.S. Geological Survey and the MDWR, is one of a series of studies done under Chapter 800 of Massachusetts legislation that quantitatively assesses the State's ground-water resources.
The purpose of this report is to describe the surface-water and ground-water resources, and to estimate the potential yields of stratified-drift aquifers in the middle and upper Charles River basin.

Yields of 15 stratified-drift aquifers in the basin were estimated by considering water that is available from intercepted ground-water discharge and induced infiltration from streams. A streamflow-accounting model was used to demonstrate the possible effects on streamflow of further development of the ground-water resources of the basin.

\section{Approach}

Geohydrologic data were gathered for this study from October 1981 through March 1985. Soils maps, logs of several hundred private and municipal wells and test holes, and logs of more than 50 test holes drilled by the U.S. Geological Survey were used to determine hydraulic properties of aquifers. Water levels in more than 100 wells were measured periodically to estimate the regional variations and seasonal fluctuations of the water table. Hydraulic properties of the glacial deposits were calculated from geologic data for about 500 wells and test holes and from results of pumping tests at several municipal wells. A marine seismic-reflection survey was completed along a 5-mile reach of the Charles River from the town line dividing Natick and Dover to the Centre Street bridge in Dover to obtain a continuous record of aquifer thickness beneath the river. Flow-duration curves were developed for 11 sites along the Charles River and its major tributaries.

A streamflow-accounting model was used to simulate the hydrology of the middle and upper Charles River basin. Several hypothetical pumping plans were devised and tested using this model to demonstrate the possible effects of pumpage on streamflow.

\section{Location and Description of the Study Area}

The Charles River basin is about $31 \mathrm{mi}$ long and 5 to $15 \mathrm{mi}$ wide, with an area of about $311 \mathrm{mi}^{2}$. The basin extends inland from Boston Harbor in a southwesterly direction through Middlesex, Norfolk, Suf- 
folk, and Worcester Counties (fig. 1). Adjoining river basins include the Boston Harbor (Mystic), Shawsheen, Concord, Blackstone, Tenmile, Taunton, and Boston Harbor (Neponset). All or parts of the cities of Boston, Brookline, Cambridge, Somerville, Newton, and Waltham are located in the basin (fig. 1). The basin, which is part of the Seaboard Lowland section of the New England Province (Fenneman, 1938), is drained by the Charles River and its major tributaries, Hopping Brook, Mine Brook, Mill River, Stop River, Bogastow Brook, Waban Brook, and Stony Brook (fig. 1).

The Charles River meanders in a generally northeastward direction about $80 \mathrm{mi}$ from its headwatérs on the south slope of Honey Hill near Echo Lake in the town of Hopkinton to its mouth at Boston Harbor (fig. 1). The river flows through extensive wetlands in its middle reaches, and stream gradients throughout the basin are relatively low. From the headwaters area in Hopkinton to Dover, a distance of about 40 river miles, the channel slope of the Charles is about $4.5 \mathrm{ft} / \mathrm{mi}$ (Wandle, 1984). The river was affected by tides below the Watertown Dam until 1908. In that year, a dam was constructed about $1 \mathrm{mi}$ above the mouth of the river. The dam was replaced by the Charles River Dam at a nearby downstream site in 1978.

Land surface in the basin is gently rolling or flat, with altitudes ranging from about 550 feet above sea level in Hopkinton to sea level at Boston Harbor. Although the lower part of the basin is heavily urbanized, about 72 percent of the upper half of the basin is covered by forests (Wandle, 1984) and contains many wetlands and small lakes and ponds. Above Watertown, the basin contains 139 lakes and ponds, 65 of which have an area of 10 acres or more. Only one lake, Cambridge Reservoir in Waltham (549 acres), is larger than 500 acres (Massachusetts Department of Environmental Quality Engineering, Division of Water Pollution Control, 1976).

The area studied was limited to the middle and upper Charles River basin (about $227 \mathrm{mi}^{2}$ ) above the U.S. Geological Survey's streamflow-gaging station in Waltham. The lower part of the basin was not included because the large amount of urban development precludes the development of water supplies in that area. Most municipal supplies in the lower basin are provided by MWRA and are diverted from sources in the Chicopee and Nashua River basins.

The average annual precipitation at the Chestnut Hill observatory in Newt on for 112 years of record ending in 1984 was 45.4 in. (National Oceanic and Atmospheric Administration, 1984). Stream diversions into the Charles River basin from ad- jacent river basins and imports of water for municipal supplies amount to about 0.8 in. of water spread evenly over the $227-\mathrm{mi}^{2}$ drainage area above Waltham. Of this total annual inflow of 46.2 in., about 18 in. leaves the basin as streamflow at Waltham, about $24 \mathrm{in}$. is transpired by plants or evaporated, and about $5 \mathrm{in}$. is diverted from the basin to the Neponset River basin through Mother Brook or is discharged to Boston Harbor through the sewer system (Walker and others, 1975).

\section{Recent (1980-83) Water Use}

During 1980-83, about $66 \mathrm{Mgal} / \mathrm{d}$ of municipally supplied water was used in the middle and upper Charles River basin and by the city of Cambridge in the lower part of the basin. This amount excludes approximately $140 \mathrm{Mgal} / \mathrm{d}$ of water supplied to the cities of Boston, Brookline, and Watertown in the lower Charles River basin from MWRA sources in the Chicopee and Nashua River basins. Of the $66 \mathrm{Mgal} / \mathrm{d}$, about $31 \mathrm{Mgal} / \mathrm{d}$ was derived from surface-water and ground-water sources in the basin, $9 \mathrm{Mgal} / \mathrm{d}$ was imported from wells in adjoining basins, and $23 \mathrm{Mgal} / \mathrm{d}$ came from MWRA out-ofbasin sources. Of the $31 \mathrm{Mgal} / \mathrm{d}$ from in-basin sources, 13 came from ground-water sources and 18 came from surface-water sources. About 88 percent of the surface water supplied from the basin (16 Mgal/d) was used by Cambridge and was pumped from the Cambridge and Stony Brook Reservoirs; about 11 percent ( $2 \mathrm{Mgal} / \mathrm{d}$ ) was pumped from Echo Lake to supply Milford; and about 1 percent $(0.2 \mathrm{Mgal} / \mathrm{d})$ was pumped from Sandy Pond to supply Lincoln (Richard H. Thibedeau, Massachusetts Department of Environmental Management, Division of Water Resources, written commun., 1986).

Some towns in the upper and middle Charles River basin discharge water through MWRA sewer connections. Franklin, Holliston, Lincoln, Medfield, Medway, Milford, Millis, and Norfolk, however, rely on septic systems or treatment plants and return almost all of their water to ground-water and surface-water systems within the basin. In 1984, about $50 \mathrm{Mgal} / \mathrm{d}$ of water flowed out of the study area and Cambridge through the MWRA sewer system. All water used in Cambridge (about $17 \mathrm{Mgal} / \mathrm{d}$ ) and about 45 percent of the water pumped from ground-water sources in the Charles River basin (6 Mgal/d) was discharged into this sewer system. In addition, about $27 \mathrm{Mgal} / \mathrm{d}$ of water from out-of-basin sources (22 Mgal/d from MWRA sources and 


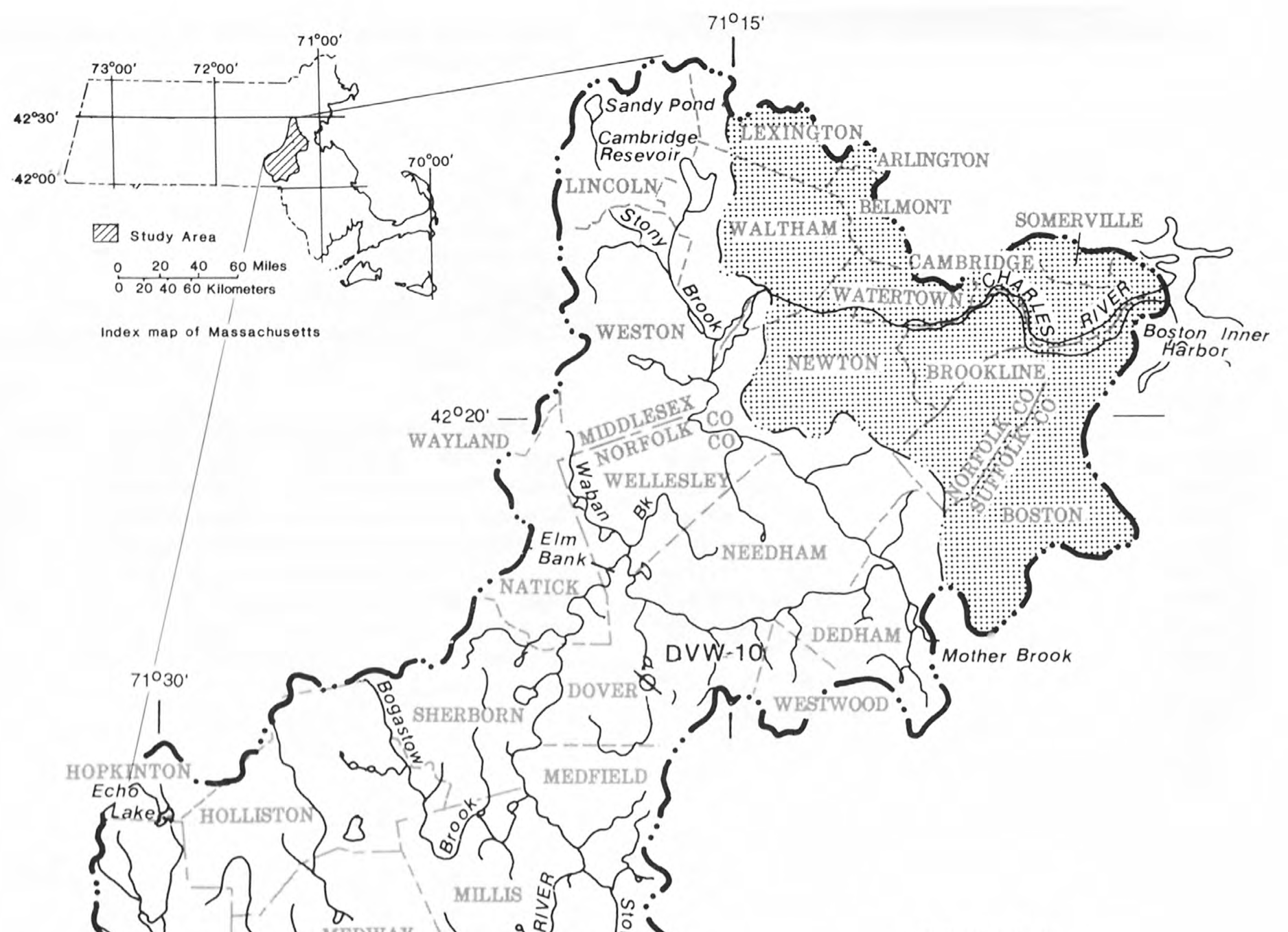

EXPLANATION
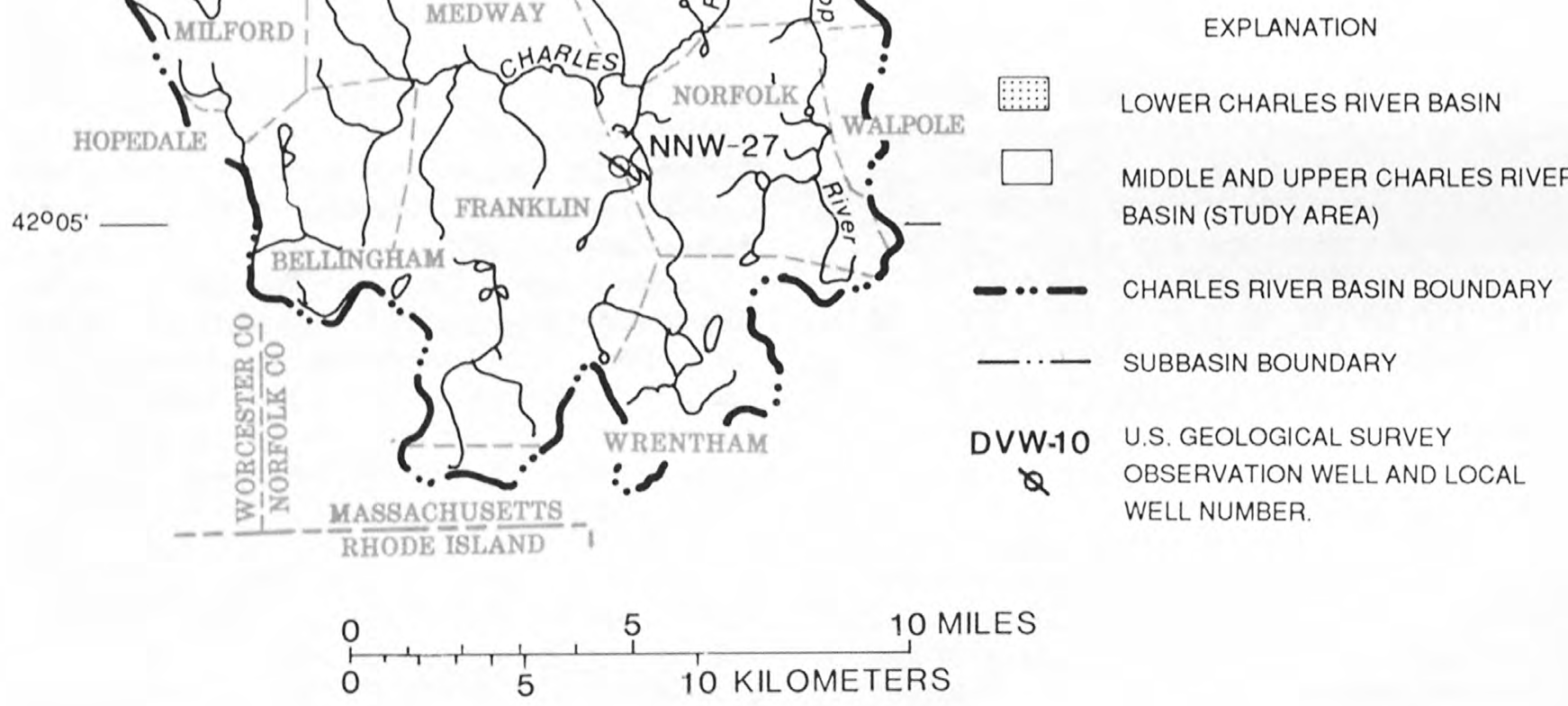

Figure 1.--Location of the study area. 
$5 \mathrm{Mgal} / \mathrm{d}$ from ground-water sources in the Neponset and Concord River basins) flowed out of the basin through the MWRA sewer system (Richard H. Thibedeau, Massachusetts Department of Environmental Management, Division of Water Resources, written commun., 1986).

Diversions of water for supply out of the Charles River basin in 1984 averaged about $68 \mathrm{Mgal} / \mathrm{d}$. About $51 \mathrm{Mgal} / \mathrm{d}$ of surface water was diverted to the Neponset River basin through Mother Brook, and about $17 \mathrm{Mgal} / \mathrm{d}$ of surface water became part of the water supply for the city of Cambridge (Richard H. Thibedeau, Massachusetts Department of Environmental Management, Division of Water Resources, written commun., 1986). Table 1 shows the amount of water used by each town in the basin during 1980-83 and the projected water use for 2000 and 2020.

\section{Acknowledgments}

The authors thank the many landowners, consulting firms, well drillers, and local and State officials who granted permission for test drilling and for providing geohydrologic data for this report.

\section{WATER RESOURCES}

\section{Surface Water}

Continuous records are available for five U.S. Geological Survey streamflow-gaging stations along the Charles River and Mother Brook, an artificial channel that diverts water from the Charles to the Neponset River. Stream stages have been recorded since 1931 on the Charles River at Waltham (station 01104500) and at the mouth of Mother Brook (station 01104000). Stages have been recorded since 1937 on the Charles River at Dover (station 01103500) and since 1959 at Wellesley (station 01104200). A fifth station on the Charles River at Millis (station 01103305) was operated as a miscellaneous-record station from 1968 to 1974 , and as a continuousrecord station from August 1974 through September 1980, after which the station was discontinued. Flow-duration curves derived from data collected during water years 1960 through 1983 at four of the streamflow-gaging stations and during water years 1975 through 1980 at the Millis station are shown in figure 2. A water year begins on October first of the previous year and ends on September 30th. The curves in figures $2 \mathrm{a}$ and $2 \mathrm{~b}$ show flows that were equaled or exceeded for the indicated percent of the time during the period of record. For example, discharge of the Charles River at Dover (figure 2a) equaled or exceeded $206 \mathrm{ft}^{3} / \mathrm{s}$ (133 Mgal/d), for 50 percent of the time during water years 1960 through 1983. The daily flows that were equaled or exceeded for various percentages of time for the periods of record for the Charles River and Mother Brook stations are shown in table 2.

Commonly reported low-flow statistics, the 7-day, 2-year and 7-day, 10-year low-flow values (7Q2 and 7Q10), for the Charles River at three streamflowgaging stations on the river also are given in table 2 in $\mathrm{Mgal} / \mathrm{d}$ rather than cubic feet per second. These low flows are stream discharges taken from a frequency curve of annual values at the 2-year and 10-year recurrence intervals. The annual values are the lowest mean discharges for seven consecutive days in each climatic year of record. A climatic year is defined as the 12-month period ending March 31 of the designated year. For example, a 7Q10 value of $8.34 \mathrm{Mgal} / \mathrm{d}$ means that the 7 -day low flow (lowest mean discharge for seven consecutive days) will be less than $8.34 \mathrm{Mgal} / \mathrm{d}$ at intervals averaging 10 years in length. In other words, there is a 10-percent chance that the 7-day low flow in any one year will be less than $8.34 \mathrm{Mgal} / \mathrm{d}$.

Flow is regulated by at least $17 \mathrm{dams}$ and control structures along the Charles River (fig. 3). These dams help to lessen effects of floods by temporarily storing water upstream of the dams. Stored water may later be released in a controlled flow. Most of the 354-foot drop in river elevation from Echo Lake in Hopkinton to the Boston Harbor occurs at the dams.

Flow in the Charles River and its tributaries is also influenced by large wetlands and diversions. Wetlands are effective in controlling flood peaks because they temporarily store water and release it slowly to the river. The first diversion was made about 1640 when a canal was dug through a meadow in Dedham to a brook that flowed into the Neponset River. In 1831, a State law was passed, and is still in effect, that allowed up to one third of the water in the Charles River to be diverted into the Neponset River through this canal, now called Mother Brook (Hall, 1986). In 1958, the control structure for Mother Brook was modified so that little or no water could be diverted from the Charles during extremely low flows. Diversions to Mother Brook range from zero to more than $1,040 \mathrm{ft}^{3} / \mathrm{s}(672 \mathrm{Mgal} / \mathrm{d})$, and the 52 -year average is $78.4 \mathrm{ft}^{3} / \mathrm{s}$ (about $50 \mathrm{Mgal} / \mathrm{d}$ ) (Richard H. Thibedeau, Massachusetts Department 
Table 1.--Recent (1980-83) and projected (2000 and 2020) municipal average day demand by towns in the middle and upper Charles River basin and by Cambridge

[Units are given in Mgal/d, million gallons per day; Data source: Richard H. Thibedeau, Massachusetts Department of Environmental Management, Division of Water Resources, written commun., 1985]

\begin{tabular}{|c|c|c|c|c|c|c|}
\hline \multirow[b]{2}{*}{$\begin{array}{l}\text { Municipalities with } \\
\text { local sources }\end{array}$} & \multicolumn{3}{|c|}{ Year } & \multicolumn{2}{|c|}{$\begin{array}{c}\text { Amount derived } \\
\text { from basin } \\
(1980-83)\end{array}$} & \multirow[t]{2}{*}{$\begin{array}{c}\text { Amount } \\
\text { exported } \\
\text { from basin } \\
\text { through sewers } \\
\quad(1980-83)\end{array}$} \\
\hline & $1980-83$ & 2000 & 2020 & $\begin{array}{l}\text { Surface } \\
\text { water }\end{array}$ & $\begin{array}{l}\text { Ground } \\
\text { water }\end{array}$ & \\
\hline Bellingham ${ }^{1}$ & 1.16 & 1.5 & 1.6 & 0 & 0.19 & 0.10 \\
\hline Cambridge $^{2}$ & 17.10 & 17.7 & 18.2 & 16.25 & 0 & 17.1 \\
\hline Dedham/Westwood ${ }^{3}$ & 3.78 & 4.5 & 5.0 & 0 & 1.65 & 1.65 \\
\hline Dover & .11 & .2 & .3 & 0 & .11 & 0 \\
\hline Franklin & 2.05 & 2.6 & 2.9 & 0 & 2.05 & 0 \\
\hline Holliston & .97 & 1.4 & 1.5 & 0 & .97 & 0 \\
\hline Lincoln ${ }^{4}$ & .45 & .5 & .6 & .22 & .02 & 0 \\
\hline Medfield $^{5}$ & 1.08 & 1.2 & 1.3 & 0 & .02 & 0 \\
\hline Medway & .72 & 1.0 & 1.1 & 0 & .72 & 0 \\
\hline Milford & 2.79 & 3.4 & 3.8 & 2.04 & .75 & 0 \\
\hline Millis & .59 & 1.0 & 1.1 & 0 & .59 & 0 \\
\hline Natick $^{6}$ & 4.33 & 4.4 & 4.8 & 0 & 0 & 3.25 \\
\hline Needham $^{7}$ & 3.53 & 3.7 & 4.1 & 0 & 2.47 & 3.3 \\
\hline Norfolk & .22 & .4 & .6 & 0 & .22 & 0 \\
\hline Sherborn $^{8}$ & 0 & 0 & 0 & 0 & 0 & 0 \\
\hline Wellesley & 2.52 & 2.9 & 3.2 & 0 & 2.52 & 2.52 \\
\hline Wrentham ${ }^{9}$ & .87 & 1.0 & 1.5 & 0 & .48 & .26 \\
\hline \multicolumn{7}{|l|}{$\begin{array}{l}\text { Municipalities supplied } \\
\text { by MWRA }{ }^{10}\end{array}$} \\
\hline Newton & 10.49 & 11.1 & 12.0 & 0 & 0 & 10.49 \\
\hline Waltham & 9.79 & 11.4 & 12.5 & 0 & 0 & 9.79 \\
\hline Weston & 1.20 & 1.3 & 1.4 & 0 & 0 & 0 \\
\hline \multicolumn{7}{|c|}{1 Includes $0.97 \mathrm{Mgal} / \mathrm{d}$ from the Blackstone River basin. } \\
\hline \multicolumn{7}{|c|}{2 Includes $0.85 \mathrm{Mgal} / \mathrm{d}$ from MWRA surface-water sources. } \\
\hline \multicolumn{7}{|c|}{3 Includes $2.13 \mathrm{Mgal} / \mathrm{d}$ from the Neponset River basin. } \\
\hline \multicolumn{7}{|c|}{4 Includes $0.21 \mathrm{Mgal} / \mathrm{d}$ from the Concord and Sudbury River basin. } \\
\hline \multicolumn{7}{|c|}{5 Includes $1.06 \mathrm{Mgal} / \mathrm{d}$ from the Neponset River basin. } \\
\hline \multicolumn{7}{|c|}{6 Includes $4.33 \mathrm{Mgal} / \mathrm{d}$ from the Concord and Sudbury River basin. } \\
\hline \multicolumn{7}{|c|}{7 Includes $1.06 \mathrm{Mgal} / \mathrm{d}$ from MWRA surface-water sources. } \\
\hline \multicolumn{7}{|c|}{8 Sherborn does not have a public water-supply system. The entire town is supplied by on-site wells. } \\
\hline \multicolumn{7}{|c|}{9 Includes $0.39 \mathrm{Mgal} / \mathrm{d}$ from the Taunton River basin. } \\
\hline 10 MWRA sources ar & ocated in & copee al & a River ba & & & \\
\hline
\end{tabular}




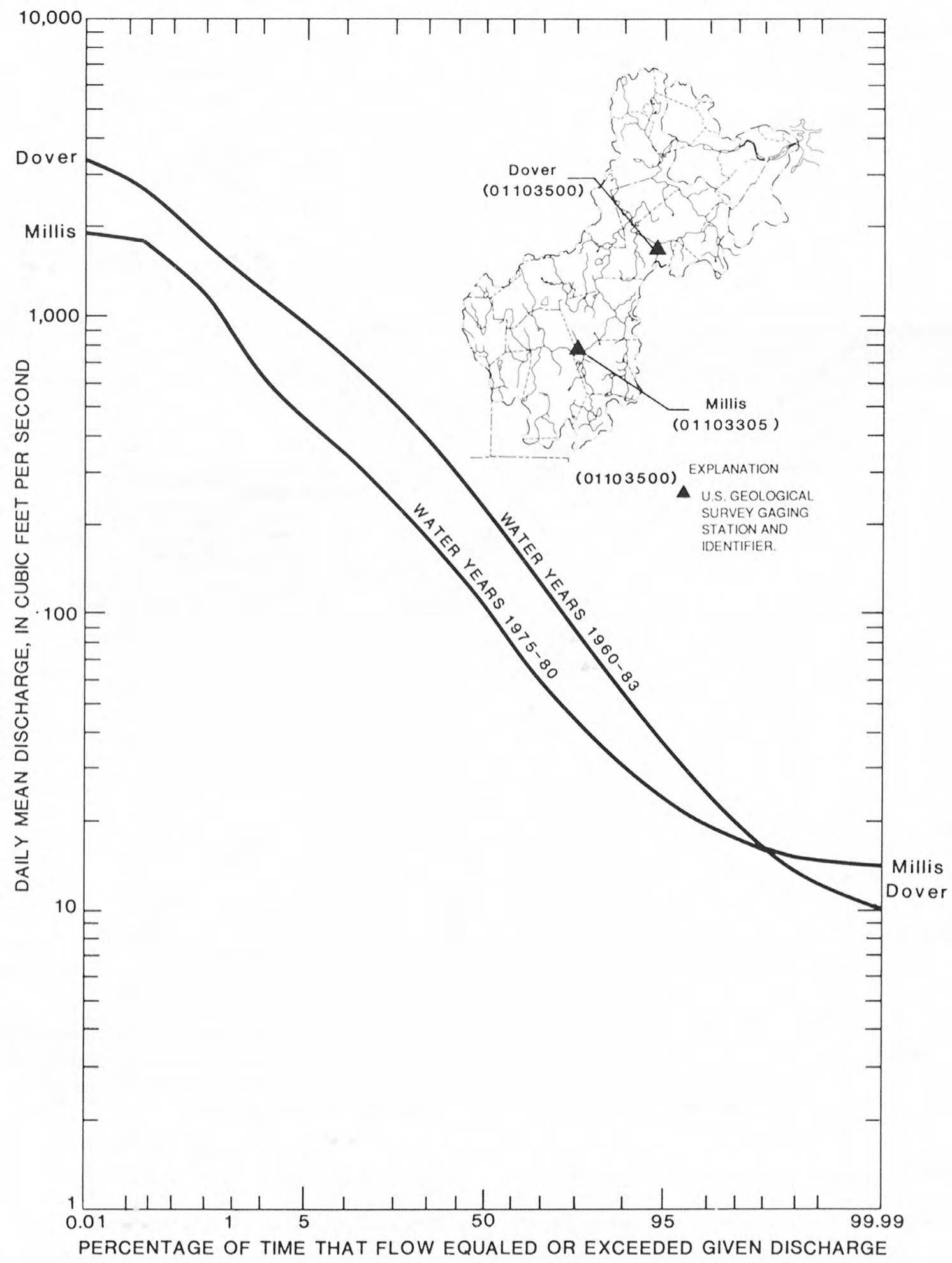

Figure 2a.--Flow-duration curves for the Charles River at U.S. Geological Survey streamflow-gaging stations at Dover, water years 1960-83, and at Millis, water years 1975-80. 


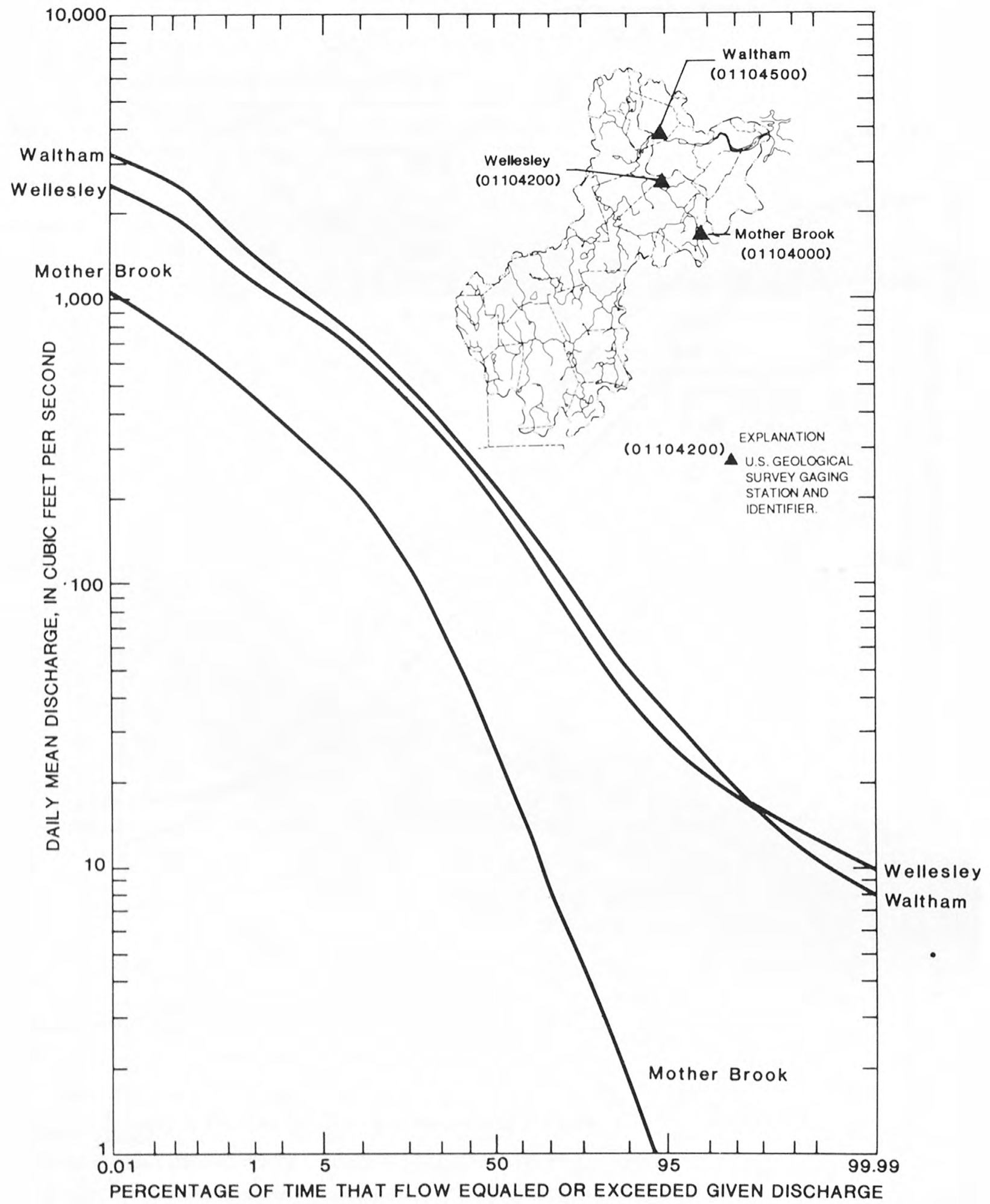

Figure 2b.--Flow-duration curves for the Charles River at selected U.S. Geological Survey streamflow-gaging stations, water years 1960-83. 
Table 2.--Low-flow statistics and flow duration of the Charles River and Mother Brook at streamflow-gaging stations near Millis, Dover, Dedham, Wellesley, and Waltham, Mass.

[From Wandle, 1984, p. 39-40; streamflow is given in Mgal/d, million gallons per day; drainage area is given in $\mathrm{mi}^{2}$, square miles; a dash indicates no computation]

\begin{tabular}{|c|c|c|c|c|c|}
\hline $\begin{array}{c}\text { Station name } \\
\text { and } \\
\text { number }\end{array}$ & $\begin{array}{c}\text { Charles River } \\
\text { near Millis } \\
(01103305)\end{array}$ & $\begin{array}{c}\text { Charles River } \\
\text { at Dover } \\
(01103500)\end{array}$ & $\begin{array}{c}\text { Mother Brook } \\
\text { at Dedham } \\
(01104000)\end{array}$ & $\begin{array}{c}\text { Charles River } \\
\text { at Wellesley } \\
(01104200)\end{array}$ & $\begin{array}{c}\text { Charles River } \\
\text { at Waltham } \\
(01104500)\end{array}$ \\
\hline $\begin{array}{l}\text { Period of } \\
\text { record }\end{array}$ & $1975-80$ & $1938-81$ & $1932-81$ & $1960-81$ & $1932-81$ \\
\hline Drainage & 84.0 & 183 & - & 211 & ${ }^{1} 227$ \\
\hline $\begin{array}{l}\text { 7-day, 2-year } \\
\text { low flow (7Q2) }\end{array}$ & - & 21.0 & - & 17.3 & 22.0 \\
\hline $\begin{array}{l}\text { 7-day, 10-year } \\
\text { low flow (7Q10) }\end{array}$ & - & 8.34 & - & 6.66 & 9.24 \\
\hline \multicolumn{6}{|l|}{$\begin{array}{l}\text { Flow duration } \\
\text { (percent) }\end{array}$} \\
\hline 99 & 11.0 & 10.3 & 0.03 & 8.72 & 3.75 \\
\hline 95 & 14.8 & 19.1 & 0.31 & 17.6 & 16.4 \\
\hline 90 & 19.6 & 26.4 & 1.16 & 25.0 & 25.9 \\
\hline 75 & 32.1 & 53.2 & 5.69 & 54.9 & 52.2 \\
\hline 70 & 37.0 & 65.3 & 8.14 & 67.9 & 69.8 \\
\hline 50 & 69.1 & 133 & 26.6 & 128 & 136 \\
\hline 25 & 132 & 273 & 76.3 & 242 & 267 \\
\hline 10 & 215 & 447 & 136 & 397 & 432 \\
\hline
\end{tabular}

${ }^{1}$ Excludes $23.7 \mathrm{mi}^{2}$ drained by Stony Brook.

of Environmental Management, Division of Water Resources, written commun., 1986). The average annual diversion of water to Mother Brook equals about 22 percent of the average flow of the Charles River at Dover. The percentage rises to about 30 percent during wet years and falls to about 17 percent during dry years. The effects of the Mother Brook diversion on streamflow in the Charles River below Dover are significant only during periods of high streamflow. During periods of low flow, diversions to Mother Brook are relatively insignificant compared to the total flow of the Charles River. The only other major diversion from the Charles River basin is into the Cambridge Reservoir system, which annually receives about $17 \mathrm{Mgal} / \mathrm{d}$ of water from the basin.

\section{Ground Water}

\section{Hydrogeologic Setting}

West of Natick, the Charles River basin is mostly underlain by igneous and metamorphic rocks of Precambrian age; east of Natick, the basin is mostly underlain by metamorphosed sedimentary and volcanic rocks of Lower Paleozoic age. Depths to bedrock range from zero where rocks are exposed at the land surface to about $200 \mathrm{ft}$ in several valleys in the basin. Water from bedrock wells comes mainly from fractures in bedrock and the highest yields occur where wells intersect many interconnected fractures. Domestic bedrock wells are commonly 


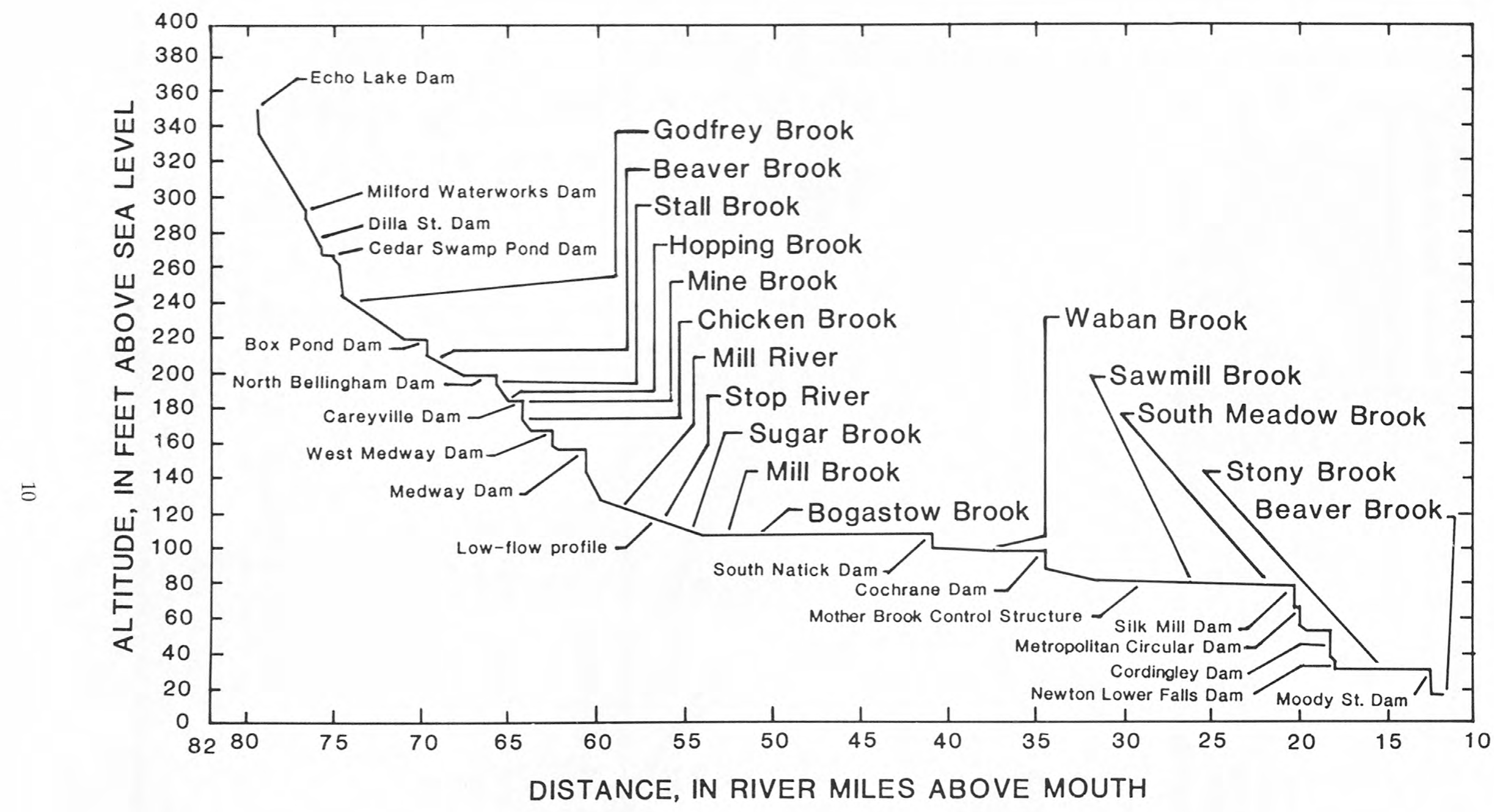

Figure 3.--Approximate location of tributaries and dams along the Charles River. 
6 to 8 in. in diameter and 50 to $300 \mathrm{ft} \mathrm{deep.} \mathrm{Yields} \mathrm{for}$ these wells are mostly from 1 to $5 \mathrm{gal} / \mathrm{min}$. Bedrock wells that are 6 to 8 in. in diameter and drilled in lowlands are reported to yield as much as $50 \mathrm{gal} / \mathrm{min}$ (Walker and others, 1975). Although these yields may be adequate for home, farm, and minor industrial needs, they are inadequate for public-water supply.

Unconsolidated till and stratified drift were deposited over bedrock during the last glacial stage, which ended about 10,000 to 15,000 years ago. Till, a poorly sorted mixture of boulders, cobbles, gravel, sand, silt, and clay, overlies most of the bedrock in the basin and is generally a poor aquifer. Wells completed in till commonly yield less than $10 \mathrm{gal} / \mathrm{min}$ (Walker and others, 1975).

Stratified drift, which was deposited in valleys and lowlands of the basin by glacial meltwater streams, is composed of sorted and layered sand, gravel, silt, and clay. Fifteen stratified-drift aquifers have been identified in the Charles River basin (fig. 4). Listed in downstream order, these aquifers are (1) Cedar Swamp Pond near Milford, (2) Weston Pond near Holliston, (3) Mine Brook near Franklin, (4) Lake Pearl near Wrentham, (5) Bellingham/Medway, (6) Mirror Lake, (7) Bogastow Brook, (8) Millis/Medfield, (9) Sherborn/Farm Pond, (10) Morse's Pond/Elm Bank, (11) Needham/Rock Meadow, (12) Cutler Park near Needham, (13) Rosemary Brook near Wellesley, (14) Stony Brook near Lincoln, and (15) Newton/Waltham near Newton. These aquifers are located along and are hydraulically connected to the Charles River and its tributaries. They underlie about $75 \mathrm{mi}^{2}$ or about 30 percent of the middle and upper Charles River basin and range in area from about 0.3 to $10 \mathrm{mi}^{2}$. Lengths range from about 1 to $10 \mathrm{mi}$; widths range from less than $0.25 \mathrm{mi}$ to more than $2 \mathrm{mi}$; and thicknesses range from zero feet, where they are in contact with till or bedrock, to greater than $100 \mathrm{ft}$ near Newton. The aquifers generally are unconfined and the upper surface of the saturated zone is the water table.

\section{Hydraulic Properties of Stratified Drift}

Geologic and hydrologic data from several hundred drillers' logs, test holcs, observation wells, and from several pumping tests were used to estimate saturated thickness, hydraulic conductivity, and transmissivity of the 15 stratified-drift aquifers in the basin.
The saturated thickness of the aquifer at each test hole and well location was calculated by subtracting the altitude of the base of the aquifer, where it is in contact with till or bedrock, from the altitude of the water table. The maximum thickness of aquifer material generally increased from about $40 \mathrm{ft}$ in the Bellingham/Stall Brook aquifer in the southwestern part of the basin to about $100 \mathrm{ft}$ in the Newton/Waltham aquifer in the northeastern part of the basin. The saturated thickness of one of the aquifers, the Morse's Pond/Elm Bank aquifer, is mostly from 20 to $40 \mathrm{ft}$, although locally it is as great as $80 \mathrm{ft}$ (fig. $5 \mathrm{a}$ ).

The average, non-directional, hydraulic conductivity of the aquifer materials at each test hole and well was estimated from laboratory-derived relations between grain size and hydraulic conductivity (table 3 ). Transmissivity at each test hole and well was estimated by multiplying the saturated thickness of each distinctive unit on a lithologic log by its estimated hydraulic conductivity. The values for all units on a log were added to find the total transmissivity at that location. Equal transmissivities at different locations in an aquifer may indicate deposits of similar hydraulic conductivity and thickness, or may be the result of thin deposits of high-conductivity stratified drift at one location and thick deposits of low-conductivity drift at another location. Estimates of transmissivity for the 15 stratified-drift aquifers are as high as $25,000 \mathrm{ft}^{2} / \mathrm{d}^{1}$ in the Newton/Waltham, Medway, Millis, Medfield, and Morse's Pond/Elm Bank aquifers in areas where materials are coarse-grained and saturated zones are thick. A transmissivity map of the Morse's Pond/Elm Bank aquifer is shown in figure 5b. The transmissivity of this aquifer is mostly from 5,000 to $10,000 \mathrm{ft}^{2} / \mathrm{d}$, although locally it may be as much as 15,000 to $25,000 \mathrm{ft}^{2} / \mathrm{d}$.

\section{Ground-Water Levels and Flow}

Ground-water levels in the Charles River basin are controlled by the hydraulic properties of aquifers and by the rate of recharge to and discharge from the ground-water system. Even though precipitation is relatively evenly distributed throughout the year, water levels vary seasonally as well as annually. Some variations are local and some

1

$\mathrm{ft}^{2} / \mathrm{d}$ is the reduced form of $\left[\left(\mathrm{ft}^{3} / \mathrm{d}\right) / \mathrm{ft}^{2}\right] \mathrm{ft}$. 
14 LOCATION AND NAME
OF AQUIFER

1. CEDAR SWAMP POND
2. WESTON POND

3. MINE BROOK

4. LAKE PEARL

5. BELLINGHAM

3OGASTOW BROOK

MILLISI MEDFIELD

9. SHERBORN/FARM POND

10. MORSE'S POND

11. NEEDHAM/ROCK MEADOW

12. CUTLER PARK

13. ROSEMARY BROOK

14. STONY BROOK

15. NEWTON/ WALTHAM
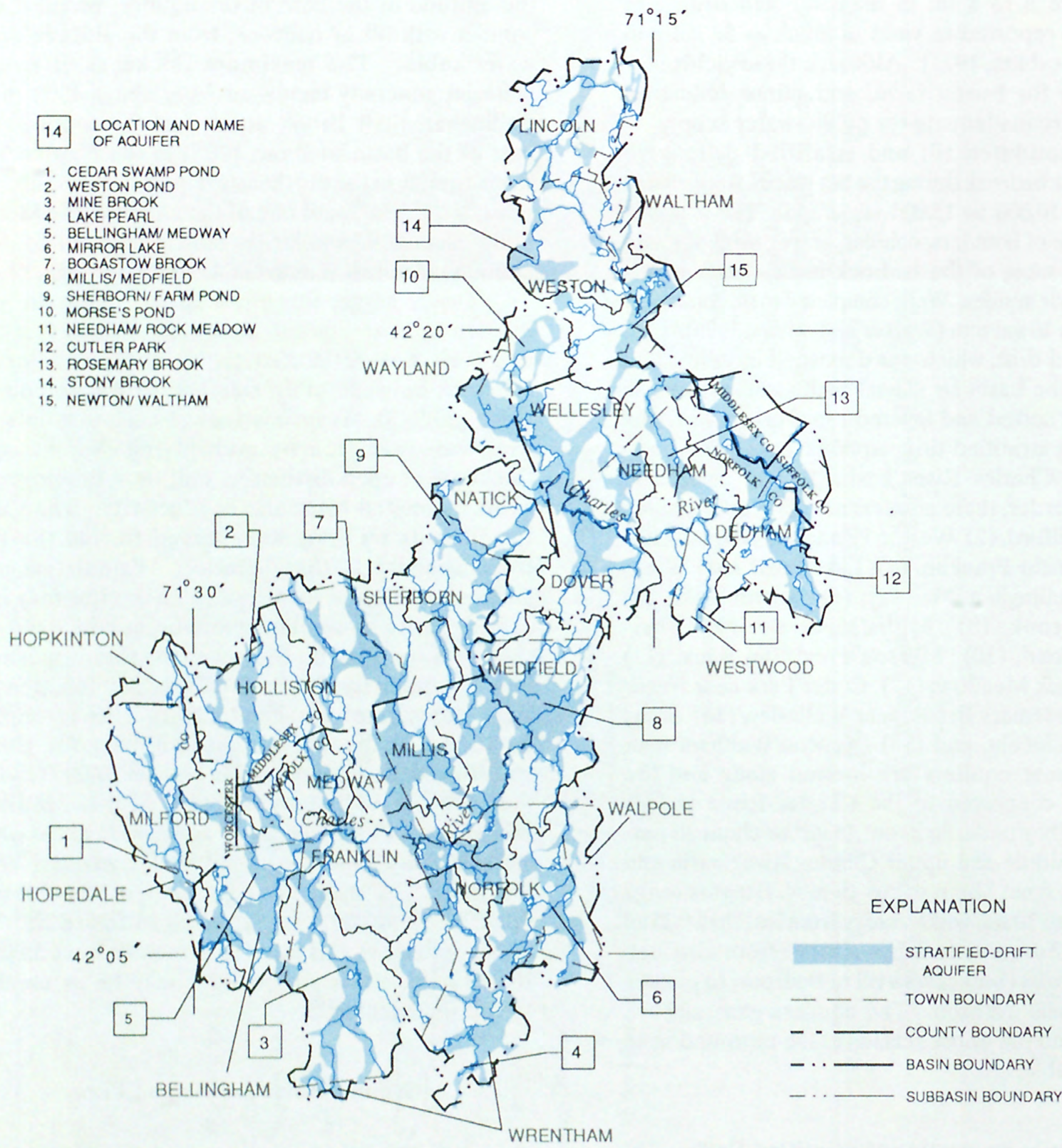

WESTWOOD

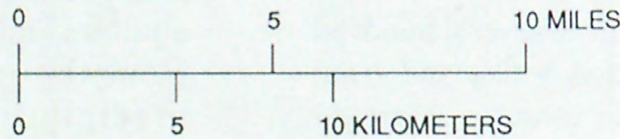

Figure 4.--Location of the 15 stratified-drift aquifers in the study area. 
Table 3.--Estimated hydraulic conductivity of stratified drift

[From Lindholm, 1980; > means greater than]

Predominant grain size

(Wentworth scale of 1922, in millimeters)
Estimated hydraulic conductivity (cubic feet per day per square foot)
Sand, very fine $(0.0625-0.125)$

$10-50$

$50-100$

$100-300$

$200-400$

Sand, medium (0.250-0.5)

Sand, medium with gravel (0.250-0.5)

$300-500$

$400-600$

Sand, coarse to very coarse with gravel (0.5-2.0)

Gravel $(>2.0)$
$500-700$ are more regional. Water levels generally decline during the late spring to early fall growing season because of evaporation and transpiration by vegetation. After the growing season, the amount of precipitation that reaches the water table increases and water levels rise again. Unusually warm winter weather and prolonged periods of wet weather can cause recharge to increase temporarily. Some examples of water-level fluctuations in wells in till, bedrock, and stratified-drift in eastern Massachusetts are shown in figures 6 and 7 . Figure 8 shows the average monthly water-level fluctuation in Dover well DVW-10 in 1984 in relation to the maximum, minimum, and average water levels during 1965-85. Water levels were above average during most of 1984, but were below average late in the year when precipitation was below average.

Ground water flows from areas of higher watertable altitude to areas of lower water-table altitude. Water levels in wells in the Charles River basin indicate that most ground water in stratified-drift aquifers flows from recharge areas toward the Charles River and its tributaries. A water-level map of the Morse's Pond/Elm Bank aquifer is shown in figure 9. This figure shows a general decline in the altitude of the water table from about 200 to $140 \mathrm{ft}$ in the northern and northeastern parts of the drainage area of the aquifer to about $100 \mathrm{ft}$ near the Charles River.

\section{Aquifer Recharge}

In Massachusetts, most ground-water recharge occurs from late winter to early spring from precipitation and melting snow and ice; little or none occurs during the late spring to early fall growing season when evapotranspiration rates are high (Frimpter, 1981). The amount of recharge depends mainly on the amount, rate, and duration of precipitation; soil types and their antecedent moisture content; amount and type of vegetation; and air temperature. Because of the large number of factors that affect recharge, it is not uniform areally or temporally and is difficult to predict for any given storm.

The annual precipitation and the water levels in Dover well DVW-10 during 1965-84 are shown in figure 10. In general, the average water level and, thus, recharge of the aquifer in the region of this well were lower during years when precipitation was below average for the period. Similarly, higher water levels during years of above-average precipitation indicate that the aquifer was receiving greater amounts of recharge.

Seasonal water-level fluctuations can be used to estimate recharge of sand and gravel aquifers (Rasmussen and Andreasen, 1959). The maximum altitude of the water table that is reached in response to a recharge event (peak level) is compared to the estimated level of the water table had no recharge event occurred (recession level). Annual recharge is approximately equal to the sum of the differences between each peak ground-water level and its corresponding recession level, multiplied by the specific yield of the aquifer (the volume of water released from a unit volume of an aquifer under a unit change in head).

For example, between January and December 1984, the ground-water level at Dover well DVW-10 rose five times in response to five recharge events (fig. 11). Recession levels were estimated for the 


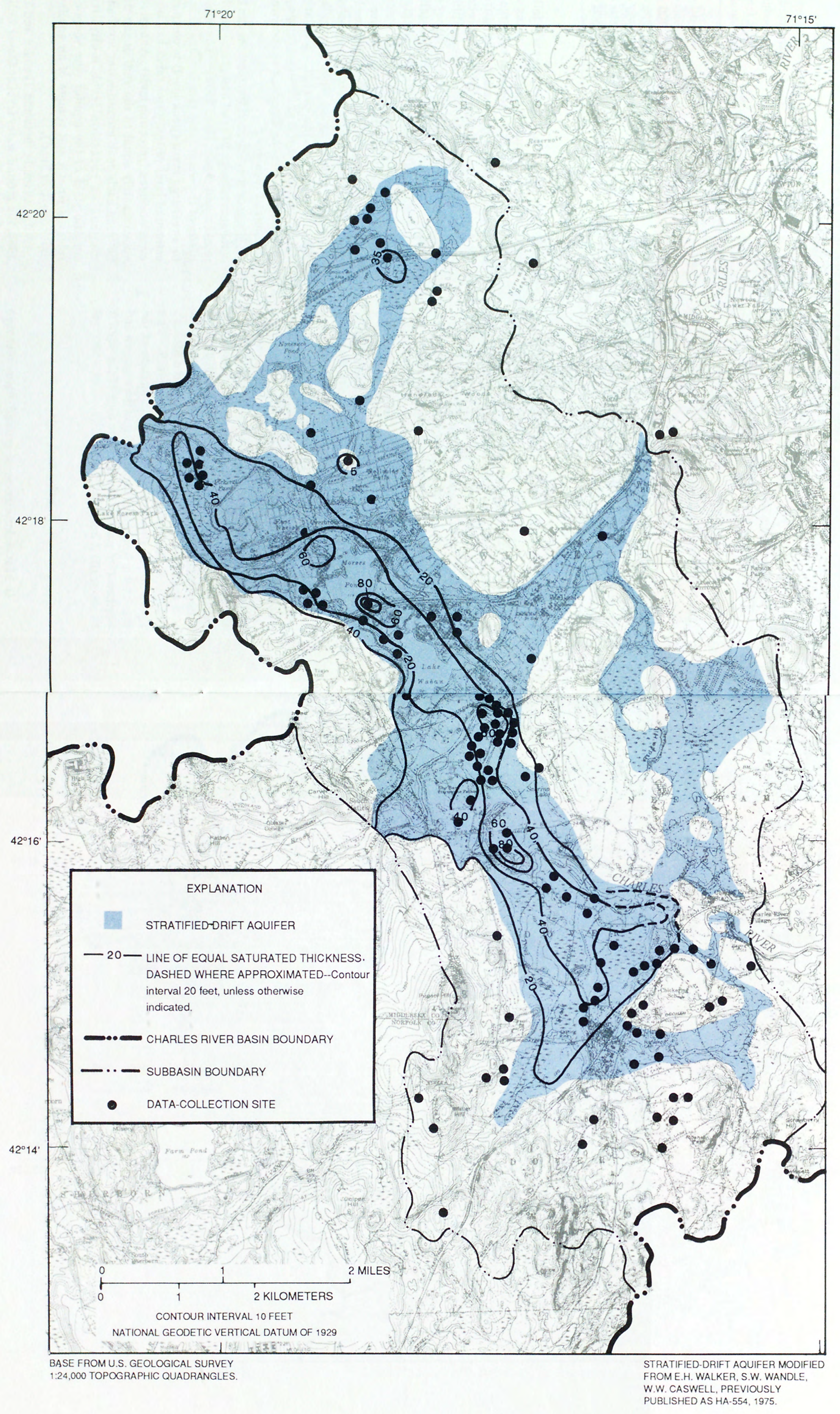




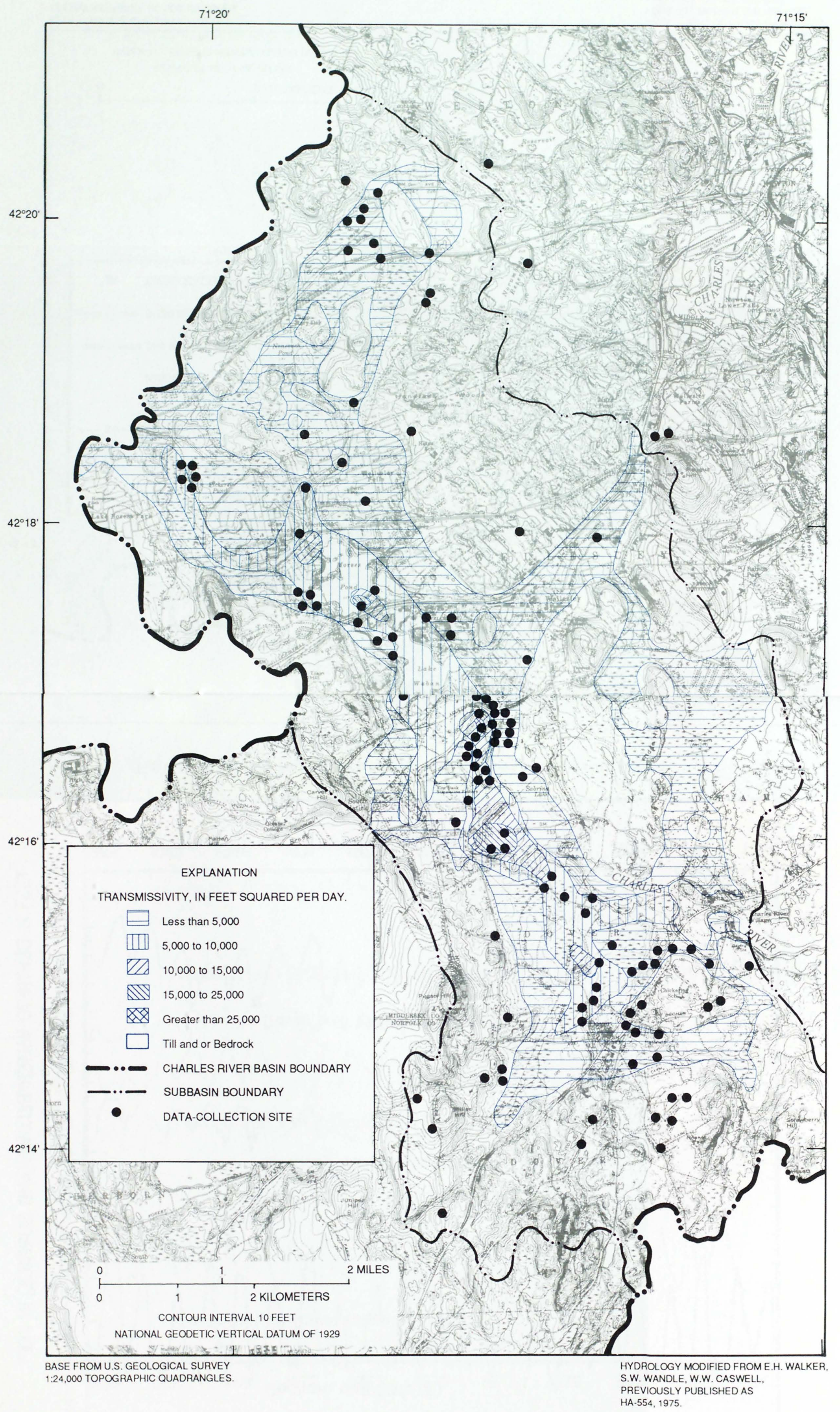




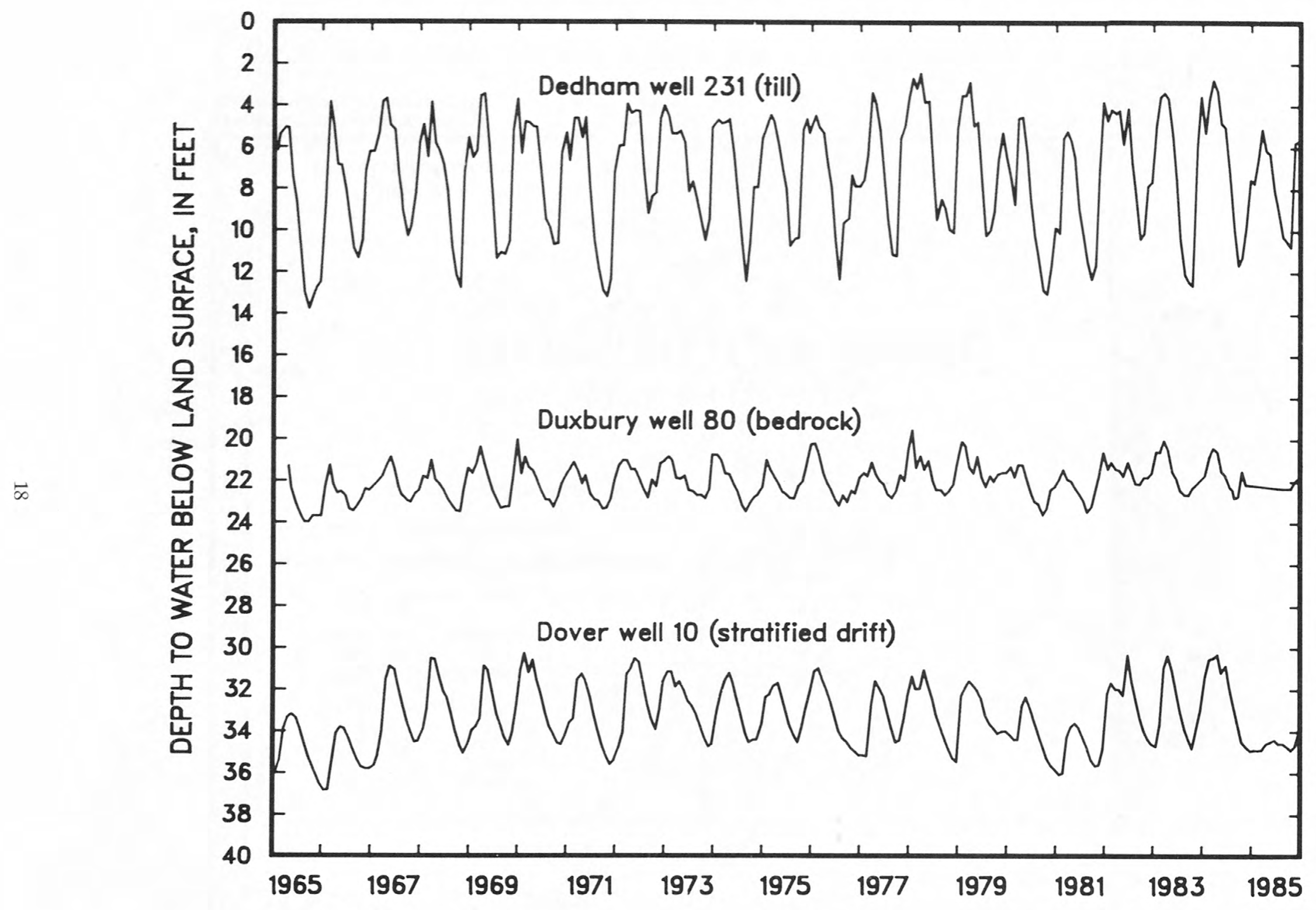

Figure 6.--Water-level fluctuations in selected wells in eastern Massachusetts, 1965-85. 


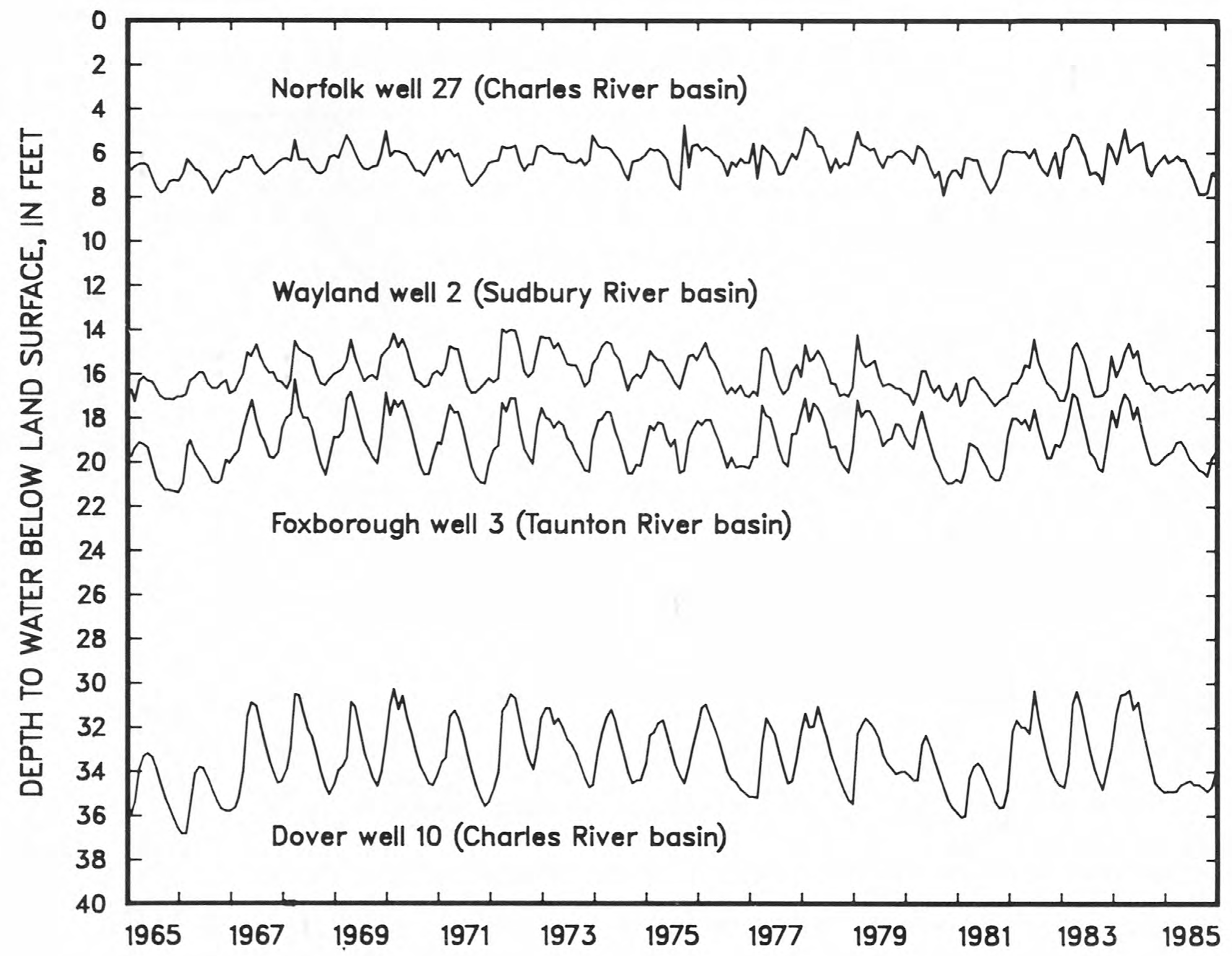

Figure 7.--Water-level fluctuations in selected wells in stratified-drift aquifers located in and near the Charles River basin, 1965-85. 


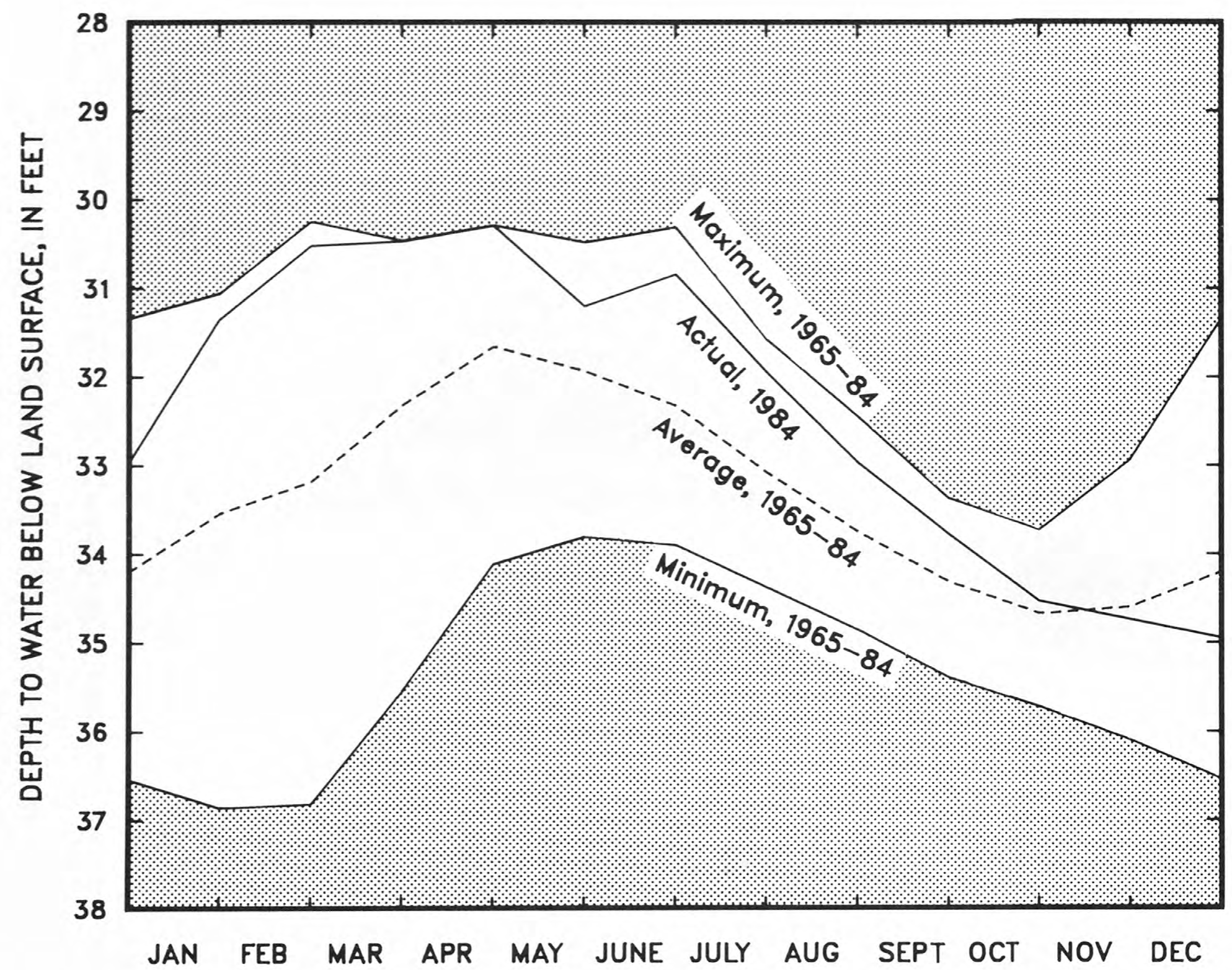

Figure 8.--Water levels in Dover well DVW-10 in 1984 compared to maximum, minimum, and average monthly water levels in well DVW-10, 1965-84. 
last two events by extrapolating the water-table declines observed prior to the events to the dates on which the recharge events occurred. The water table had not reached a peak level before each of the first three recharge events. Therefore, recession lines for these events were assumed to be approximately parallel to the recession lines constructed for the last two recharge events of 1984 . The differences between the peak and recession levels for the five events were $2.3,1.6,1.7,1.1$, and 1.1 for a total of $7.8 \mathrm{ft}$. Using reported values for specific yield for aquifer materials similar to those that occur at Dover well DVW-10, the total annual recharge can be calculated by using the following equation (Rasmussen and Andreasen, 1959):

$$
\mathrm{R}=(\mathrm{H})(\mathrm{Sy})(12),
$$

where $R$ is annual recharge rate, in inches per year;

$\mathrm{H}$ is total difference in ground-water level, in feet; and

Sy is specific yield.

The lithologic log for Dover well DVW-10 indicates materials that range from very fine sand to coarse gravel (Walker and others, 1977). A reasonable range of specific yield for these particle sizes is 0.15 to 0.30 (Johnson, 1967). Recharge estimates made by this method are limited by the precision to which the specific yield of the aquifer at the water table near well DVW-10 is known. Using the above method and a range of specific yields of 0.15 to 0.30 , the recharge rate for the DVW-10 site in 1984 would range from 14 to $28 \mathrm{in} / \mathrm{yr}$. In comparison, estimates of average annual recharge rates on sandy outwash on Nantucket Island in Massachusetts ranged between 16.7 and 26.1 inches per year for the period 1964 to 1983 (Knott and Olimpio, 1986).

In addition to recharge from precipitation, water also enters stratified-drift aquifers from adjacent till. In a similar geologic area of southern Maine, Morrissey (1983) estimated that leakage from till to stratified drift was $0.5\left(\mathrm{ft}^{3} / \mathrm{s}\right) / \mathrm{mi}^{2}$ of drainage area covered by till. Using this leakage rate, the leakage from till into the stratified-drift aquifers in the Charles River basin is about $76 \mathrm{ft}^{3} / \mathrm{s}$ (49 Mgal/d) upstream of Waltham, or about $7 \mathrm{in.} \mathrm{of}$ water per year.

Infiltration induced from streams by nearby pumped wells may be the largest potential source of recharge to aquifers in the Charles River basin. A cone of depression (area of lowered water level around a pumped well) can cause the potentiometric head beneath the stream to drop below the water level in the stream. The hydraulic gradient between the stream and the water table is thus steepened or reversed, causing stream water to infiltrate through the streambed and move toward the well. The amount of water that infiltrates through a streambed depends upon the hydraulic properties of the streambed and the aquifer, and on the hydraulic gradient produced by pumping.

\section{Aquifer Discharge}

Most ground water in a stratified-drift aquifer that discharges to surface water or pumped wells originated as precipitation that directly recharged the aquifer from land surface, as water that infiltrated the aquifer from losing streams, or as water that flowed into the aquifer from adjacent till and bedrock. Some water in these aquifers is also derived from wastewater return flows. Under natural conditions, aquifers discharge water to streams, ponds, lakes, and wetlands. During pumping, some of this ground water is intercepted and withdrawn by wells.

Aquifer discharge to streams can be estimated from the 90- to 99.9-percent flow duration on flowduration curves. At these low flows, streamflow is mostly or entirely ground-water discharge. For example, if all streamflow in the Charles River basin at the 95-percent flow duration is assumed to be ground-water discharge, then the ground-water discharge determined from the flow-duration curve of the Charles River at Waltham is at least $30 \mathrm{ft}^{3} / \mathrm{s}$ (19 Mgal/d) during an average year (fig. 2b). This equals about 1.8 in. of water per year when spread over the entire drainage area upstream from Waltham.

Flow-duration curves that represent streamflow at relatively undeveloped reaches of streams commonly show that streamflow increases downstream. But as the land becomes increasingly urbanized and as the amount of water diverted or withdrawn by wells increases, this pattern can change. Seven sets of base-flow measurements taken on the Charles River and its tributaries between August 24, 1982, and August 26, 1983, showed downstream accretion of streamflow, indicating that ground water was discharging into the river. 

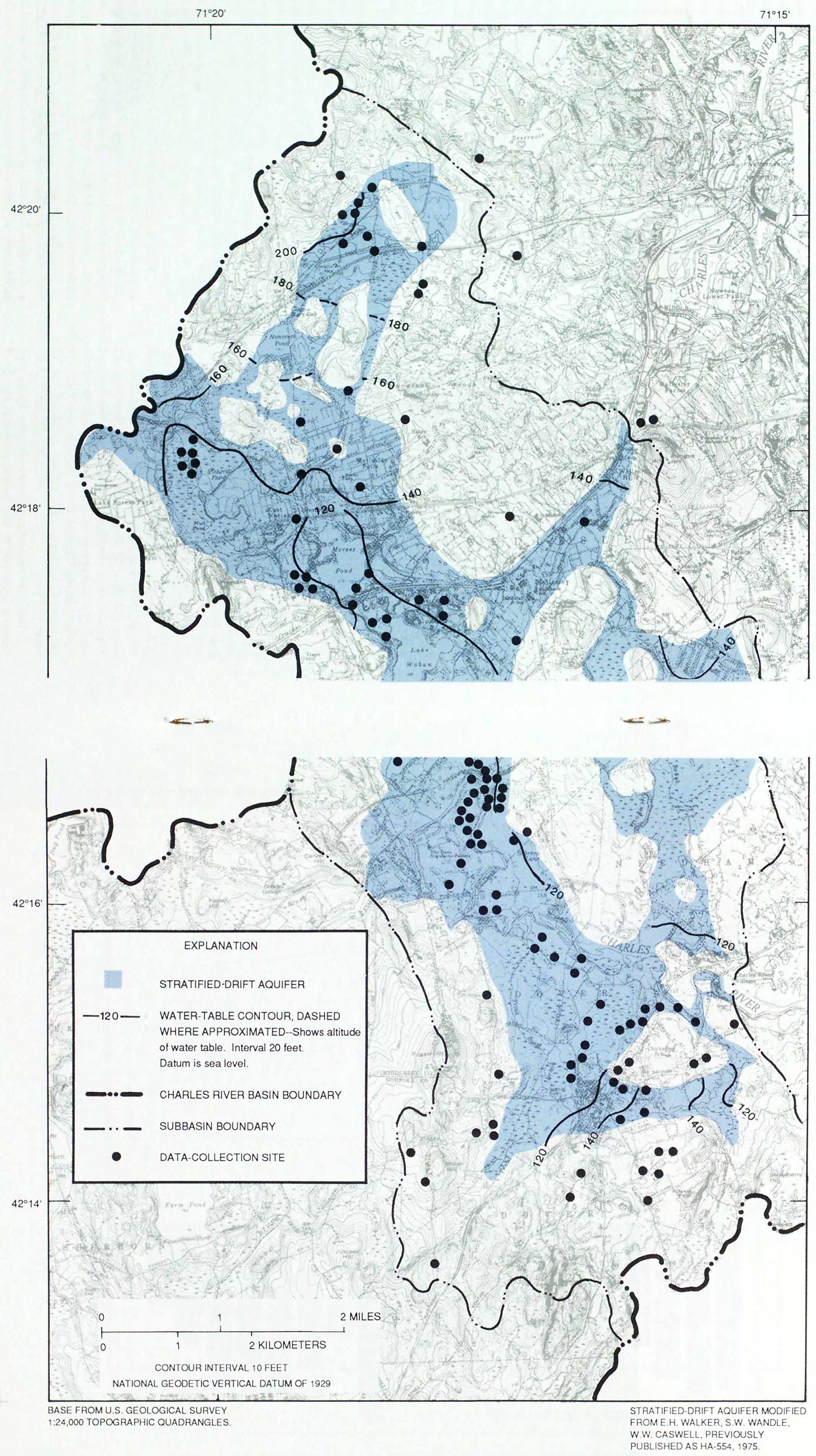

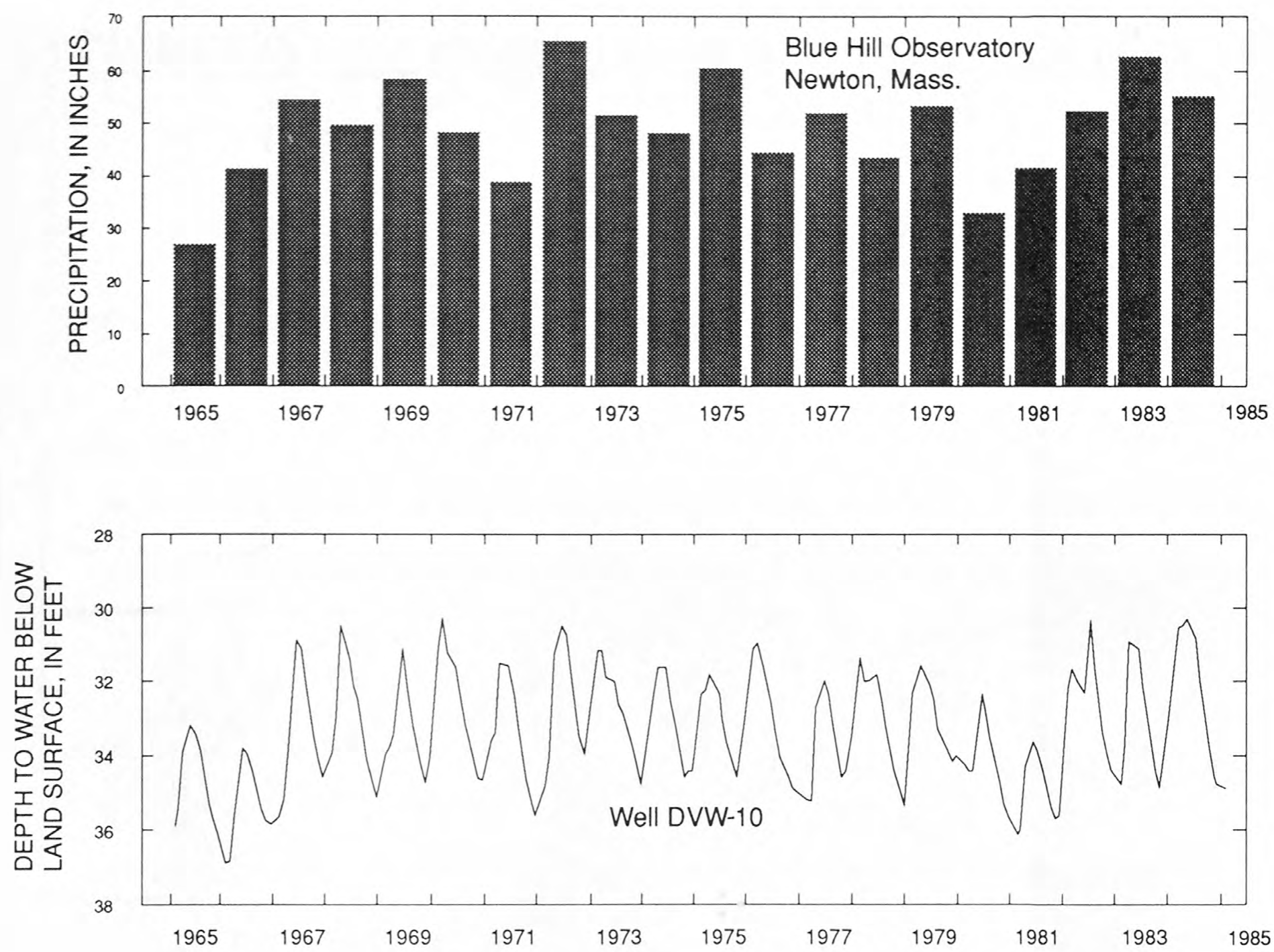

Figure 10.--Relation between precipitation and ground-water levels for Dover well DVW-10, 1965-84. 


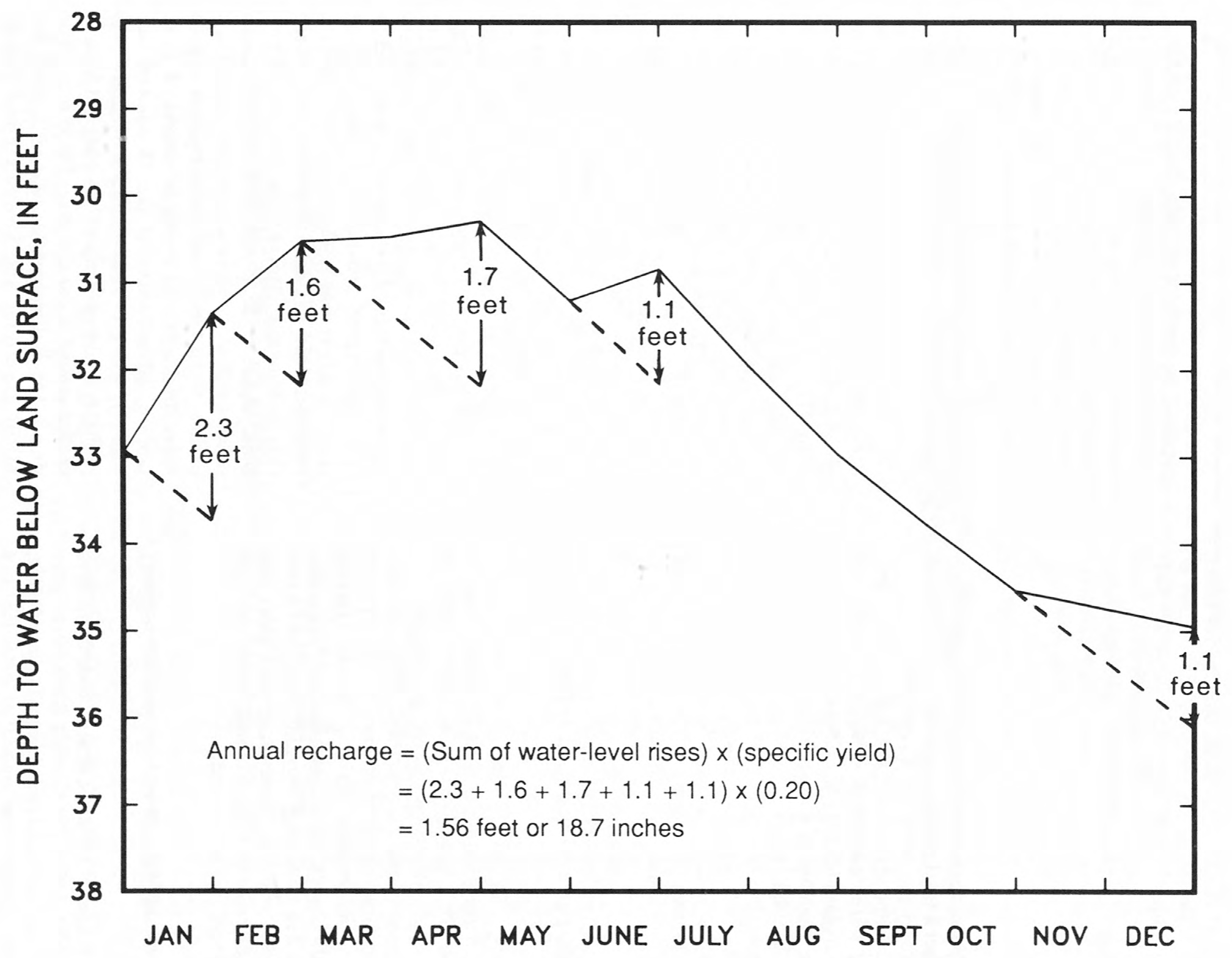

Figure 11.--Hydrograph from Dover well DVW-10 for 1984 and equation used to determine ground-water recharge. 


\section{AQUIFER YIELDS}

Yields of the 15 aquifers in the Charles River basin were estimated by considering the amount of water available through interception of groundwater which would normally discharge to the Charles River or one of its tributaries. In addition, aquifer yields were estimated for seven aquifers where pumping of wells could induce water from the Charles River to infiltrate through the streambed and recharge the aquifers. Ground water so derived is hereafter referred to as induced infiltration.

The yields for individual aquifers should not be added to get a total ground-water yield for the basin because development of one aquifer may affect the amount of water available to another. For example, if ground-water discharge from an aquifer to a stream decreases because of pumping, there will be less water available to downstream aquifers for induced infiltration.

The estimates of aquifer yield given in this section were made assuming that the aquifers were undeveloped. In the section "Predicted effects of groundwater development on the Charles River", the effects of aquifer development on streamflow are described.

\section{Yields from Intercepted Ground-Water Discharge and Induced Infiltration}

Under long-term conditions (180 days or more), recharge to aquifers in New England is mostly derived from precipitation and will cause an aquifer to continuously discharge ground water to streams, ponds, lakes, and wetlands. This groundwater discharge consists of most of the flow of streams during low-flow periods. On the average, aquifer discharge equals aquifer recharge and ground water in storage remains about the same from year to year. If, however, ground-water discharge is diverted by wells, streamflow will decrease by the amount that is diverted.

\section{Yields without Maintained Minimum Streamflow}

The potential yields of stratified-drift aquifers in the middle and upper Charles River basin were estimated by a method developed by Thomas (1966). The method estimates the amount of water that can be derived from wells that intercept ground water which would have otherwise discharged to streams. A family of flow-duration curves which relate ground-water discharge at low flow to geology of a stream's drainage area was developed by Thomas from analysis of several continuous-record streamflow gaging stations (fig. 12). The curves are for unregulated streams that have a mean flow of $1.16 \mathrm{Mgal} / \mathrm{d} / \mathrm{mi}^{2}$, and are based on the period from October 1930 to September 1960. The lower part of these curves (flows equaled or exceeded 80 to 99.9 percent of the time) show that low flows are related to the percentage of drainage area underlain by coarse-grained stratified drift and by till-mantled bedrock. Studies summarized by Cervione and others (1972) indicate that both average annual recharge from precipitation and average annual ground-water discharge are about three times greater in areas underlain by coarse-grained stratified drift than in areas underlain by till and bedrock. Because the curves in figure 12 were derived for drainage areas in Connecticut rather than eastern Massachusetts, the estimates derived from them were adjusted on a basis of mean flow per unit area in the Charles River basin and in Connecticut, as recommended by Thomas. A ratio of 0.92 was calculated for the Charles River basin by dividing the mean runoff per square mile at the Dover gaging station $\left(1.07 \mathrm{Mgal} / \mathrm{d} / \mathrm{mi}^{2}\right)$ by the mean runoff per square mile for the Connecticut streamflow-gaging stations used to develop the curves (1.16 Mgal $\left./ \mathrm{d} / \mathrm{mi}^{2}\right)$.

For the middle and upper Charles River basin, a map of ground-water favorability (Walker and others, 1975) was used to determine the percentage of each basin covered by stratified drift. Streamflows at the 95- and 99-percent flow durations on the flow-duration curves developed for streams in the basin provided estimates of potential yield from intercepted ground-water discharge, unadjusted for current withdrawals and diversions (columns 6 and 7, table 4). If wells are placed so that they continually intercept an amount of ground water equal to these yield estimates, streams may cease to flow along some stream reaches during periods when flow is entirely composed of groundwater discharge. As shown in columns 6 and 7 of table 4, all but three of the 15 aquifers, Cedar Swamp, Rock Meadow, and Rosemary Brook, probably could yield more than $1 \mathrm{Mgal} / \mathrm{d}$ from intercepted ground-water discharge for 95 percent of the time. The Bellingham/Medway, Bogastow Brook, Millis/Medfield, and Morse's Pond/Elm Bank aquifers have the highest potential yields from intercepted ground-water discharge, $4.23 \mathrm{Mgal}$ or more at the 95-percent flow duration. The rates of 


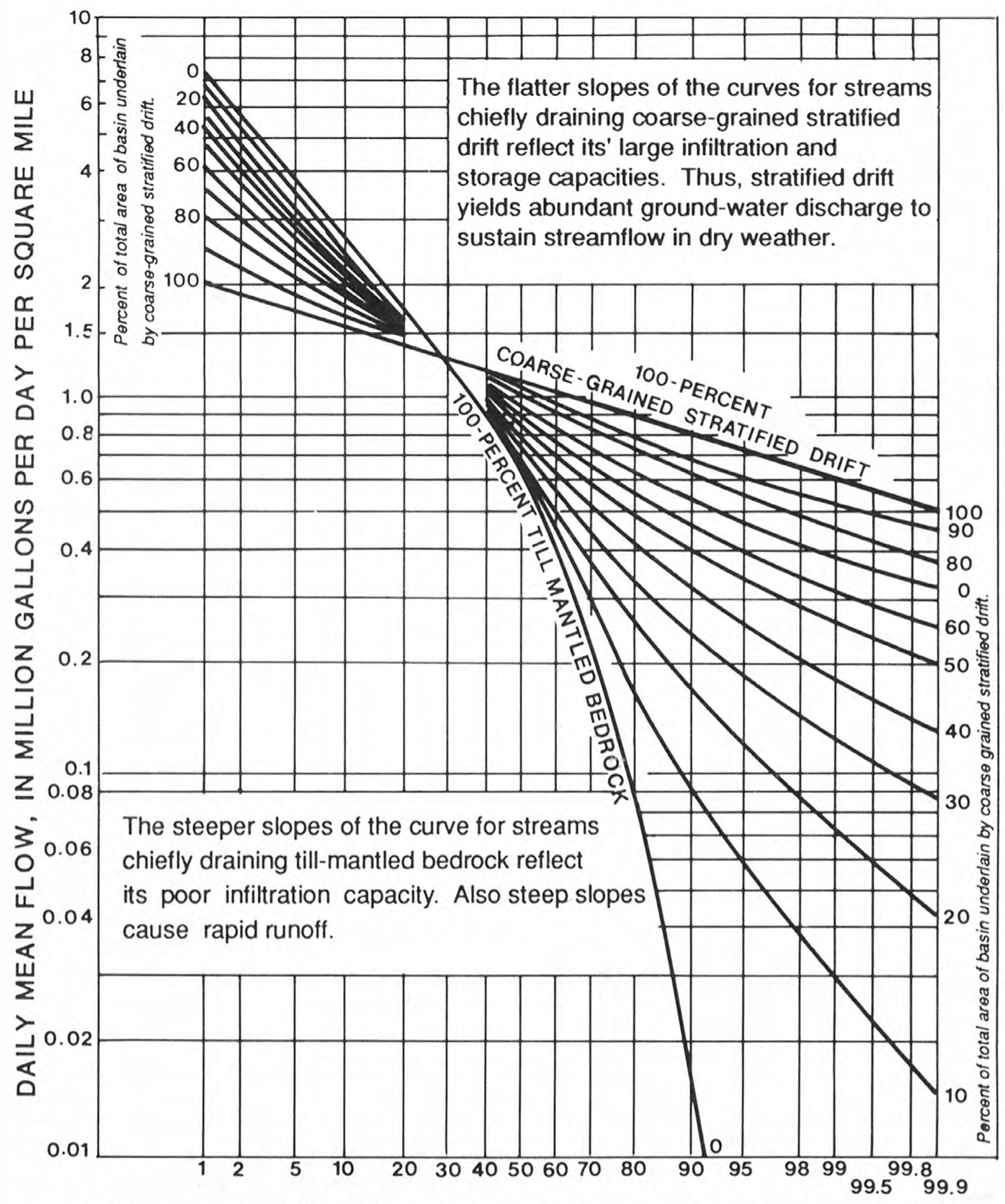

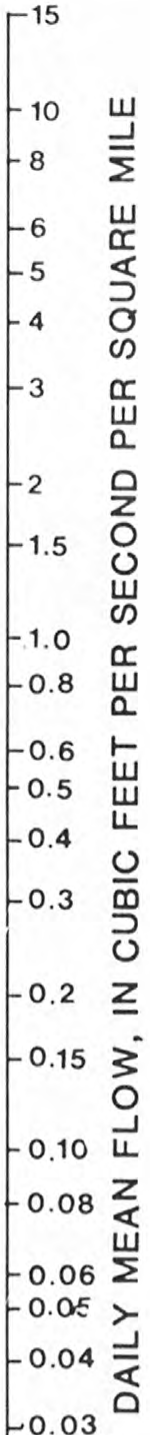

PERCENTAGE OF TIME FLOW EQUALED OR EXCEEDED THAT SHOWN

Figure 12.--Effects of basin geology on streamflow [From Cervione and others, 1982, fig. 3, based on Thomas, 1966, fig. 1.] 
Table 4.--Estimated natural yield from stratified-drift aquifers in the Charles River basin with no maintained minimum streamflow [Quantities of water are given in Mgal/d, million gallons per day; area is given in $\mathrm{mi}^{2}$, square miles; a dash indicates no computation]

\begin{tabular}{|c|c|c|c|c|c|c|c|}
\hline & Drainage area & Stratified-drift area & Estimated subbasin yield & $\begin{array}{l}\text { Estimated streamflow avail- } \\
\text { able for induced infiltration }\end{array}$ & Estimated & total yield & Actual yield at gaging station ${ }^{b}$ \\
\hline ame & Subbasin Total & Subbasin Total & $\begin{array}{cc}\text { 95-percent } & 99 \text {-percent } \\
\text { flow duration } & \text { flow duration }\end{array}$ & $\begin{array}{cc}\text { 95-percent } & 99 \text {-percent } \\
\text { flow duration } & \text { flow duration }\end{array}$ & $\begin{array}{l}\text { 95-percent } \\
\text { flow duration }\end{array}$ & $\begin{array}{l}\text { 99-percent } \\
\text { flow duration }\end{array}$ & 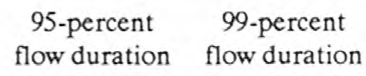 \\
\hline
\end{tabular}

\begin{tabular}{|c|c|c|c|c|c|c|c|c|c|c|c|c|}
\hline (1) & (2) & (3) & (4) & (5) & (6) & (7) & $(8)$ & (9) & (10) & (11) & (12) & (13) \\
\hline 1. Cedar Swamp & 14.5 & - & 1.69 & $\cdot$ & 0.88 & 0.47 & - & - & 0.88 & 0.47 & - & - \\
\hline 2. Weston Pond & 17.3 & - & 3.41 & - & 1.99 & 1.11 & - & - & 1.99 & 1.11 & - & - \\
\hline 3. Mine Brook & 14.1 & - & 4.12 & - & 2.27 & 1.62 & - & - & 2.27 & 1.62 & - & - \\
\hline 4. Lake Pearl & 13.8 & - & 4.27 & - & 2.44 & 1.71 & - & - & 2.44 & 1.71 & - & - \\
\hline 5. Bellingham/Medway & 24.2 & 83.9 & 7.34 & 20.8 & 4.23 & 2.90 & 7.58 & 4.91 & 11.8 & 7.81 & 14.8 & 11.0 \\
\hline 6. Mirror Lake & 12.8 & - & 4.93 & - & 2.94 & 2.01 & - & - & 2.94 & 2.01 & - & - \\
\hline 7. Bogastow Brook & 23.4 & - & 7.52 & - & 4.42 & 3.02 & - & - & 4.42 & 3.02 & - & - \\
\hline 8. Millis/Medfield & 20.3 & 140 & 9.37 & 42.6 & 5.69 & 4.30 & 19.2 & 12.8 & 24.9 & 17.1 & - & - \\
\hline 9. Sherborn/Farm Pond & 15.4 & 156 & 3.67 & 46.3 & 2.05 & 1.23 & 24.9 & 17.1 & 27.0 & 18.3 & - & - \\
\hline 10. Morse's Pond/Elm Bank & 26.6 & 183 & 9.99 & 56.3 & 5.87 & 4.04 & 26.9 & 18.4 & 32.8 & 22.4 & 19.1 & 10.3 \\
\hline 11. Needham/Rock Meadow & 9.07 & 192 & 1.13 & 57.4 & .63 & .33 & 32.8 & 22.4 & 33.4 & 22.7 & - & - \\
\hline 12. Cutler Park & 19.2 & 211 & 5.86 & 63.3 & 3.36 & 2.33 & 33.4 & 22.7 & 36.8 & 25.0 & 17.6 & 8.72 \\
\hline 13. Rosemary Brook & 3.86 & - & 1.19 & - & .68 & .48 & - & - & .68 & .48 & - & - \\
\hline 14. Stony Brook & 15.3 & - & 3.50 & - & 1.97 & 1.19 & - & - & 1.97 & 1.19 & - & - \\
\hline 15. Newton/Waltham & 11.7 & 242 & 2.76 & 70.6 & 1.56 & .93 & 39.5 & 26.7 & 41.1 & 27.6 & 16.4 & 3.75 \\
\hline
\end{tabular}

\footnotetext{
a Assumes no development of upstream resources.

b Actual yields taken from table 2.
} 
ground-water discharge from these three aquifers are high because their drainage areas are large and contain a large percentage of stratified drift.

In addition to water available from intercepted ground-water discharge, streamflow entering the upstream end of each aquifer may be available for induced infiltration. Yields available from induced infiltration from the Charles River were estimated for seven aquifers that partly underlie the river and for which sufficient data are available: Bellingham/Medway, Millis/Medfield, Sherborn/Farm Pond, Morse's Pond/Elm Bank, Needham/Rock Meadow, Cutler Park and Newton/Waltham aquifers. The streamflow-gaging stations near Millis, Dover, Wellesley and Waltham are located at the downstream ends of the Bellingham/Medway, Morse's Pond/Elm Bank, Cutler Park and Newton/Waltham aquifers respectively. For each of the seven aquifers, the estimated streamflow available for induced infiltration listed in columns 8 and 9 of table 4 are the sum of all subbasin yields upstream from the aquifer subbasin listed in columns 6 and 7 at 95- and 99-percent flow duration respectively. For each of the seven aquifers (rows 5, 8-12 and 15 in table 4) estimated total yields (columns 10 and 11) were calculated by adding the estimated subbasin yields (columns 6 and 7 ) and the estimated streamflow available for induced infiltration (columns 8 and 9) at 95- and 99-percent flow duration respectively. These estimates of total yield (columns 10 and 11) represent maximum potential yields assuming no development of water supply or diversions in the basin and assuming that all available streamflow could be induced to infiltrate. For comparison, the actual yields computed from records at the gaging stations located at the downstream ends of the Bellingham/Medway, Morse's Pond/Elm Bank, Cutler Park and Newton/Waltham aquifers are listed in columns 12 and 13 in table 4. These figures (columns 12 and 13), which also appear in table 2 , represent water available for induced infiltration under development and diversion conditions over the periods of streamflow measurement (figures $2 \mathrm{a}$ and $2 \mathrm{~b}$ ). These amounts of water potentially are available to each aquifer for induced infiltration and, except for the upstream Bellingham/Medway aquifer, these estimates are substantially less than the estimated streamflow available for induced infiltration under undeveloped conditions (columns 8 and 9). The yields given in table 4 assume that all infiltrated streamflow is withdrawn by the wells. However, the actual amount that can be infiltrated depends on the area of the streambed affected by drawdown, the vertical per- meability of the streambed and the aquifer, the vertical hydraulic gradient across the streambed, and stream-water temperature.

Theoretical total yields for each aquifer can be obtained by adding the yields from intercepted ground-water discharge and yields from induced infiltration, as has been done in columns 10 and 11 in table 4. For the 95-percent flow duration, total yields range from about $12 \mathrm{Mgal} / \mathrm{d}$ for the Bellingham/Medway aquifer to about $40 \mathrm{Mgal} / \mathrm{d}$ for the Newton/Waltham aquifer. However, because pumping large amounts of ground water causes streamflow to decline or even to cease during low-flow periods, the theoretical yields need to be adjusted if specified minimum streamflows are to be maintained.

\section{Yields with Maintained Minimum Streamflow}

The yields from ground-water discharge given in table 4 were adjusted so that the flow in streams crossing aquifers would not fall below specified low streamflows. For this analysis, two commonly reported low-flow criteria were chosen as examples: the 7-day, 10-year low flow (7Q10) and an average stream gain of $0.2\left(\mathrm{ft}^{3} / \mathrm{s}\right) / \mathrm{mi}^{2}, 0.13(\mathrm{Mgal} / \mathrm{d}) / \mathrm{mi}^{2}$, of drainage area. The $7 \mathrm{Q} 10$ low flows shown in column 2 of table 5 for each aquifer were estimated using an analytical method developed by Cervione and others (1982). This method, like the method by Thomas discussed above, is based on a relation between the low flow in streams and on the geology of the upstream drainage area. The major assumptions of the method, which are reasonably valid in the middle and upper Charles River basin, are--

1. The 7Q10 low flow is derived entirely from ground-water discharge.

2. The water-bearing units termed coarsegrained stratified drift have a relatively high ground-water storage capacity and transmissivity, and those termed till-mantled bedrock have a relatively low storage capacity and transmissivity.

3. The areal differences in ground-water evapotranspiration are not large enough to affect the 7Q10 low flows significantly.

4. The ground-water and surface-water drainage divides are coincident and can be defined by the topographic drainage divides. 
Table 5.--Estimated natural and actual yields from stratified-drift aquifers in the Charles River basin with maintained minimum streamflow

[Yields are in Mgal/d, million gallons per day; maintenance levels are in $(\mathrm{Mgal} / \mathrm{d}) / \mathrm{mi}^{2}$, million gallons per day per square mile;

7Q10, (7-day, 10-year low flow); a dash indicates no computation]

\begin{tabular}{|c|c|c|c|c|c|c|c|c|c|c|c|c|}
\hline \multirow[b]{4}{*}{ Aquifer name } & & & \multirow{2}{*}{\multicolumn{4}{|c|}{ Aquifer yield available with streamflow maintained at: ${ }^{\text {a }}$}} & \multicolumn{6}{|c|}{ Actual streamflow at gaging stations } \\
\hline & & & & & & & \multirow{2}{*}{\multicolumn{2}{|c|}{$\begin{array}{l}\text { Target streamflow } \\
\text { maintenance level }\end{array}$}} & \multicolumn{4}{|c|}{ Aquifer yield when streamflow maintained at: } \\
\hline & \multicolumn{2}{|c|}{$\begin{array}{l}\text { Target streamflow } \\
\text { maintenance level }\end{array}$} & \multicolumn{2}{|c|}{ 7Q10 } & \multicolumn{2}{|c|}{$.13(\mathrm{Mgal} / \mathrm{d}) / \mathrm{mi}^{2}$} & & & \multicolumn{2}{|c|}{$7 \mathrm{Q} 10$} & \multicolumn{2}{|c|}{$.13(\mathrm{Mgal} / \mathrm{d}) / \mathrm{mi}^{2}$} \\
\hline & $7 \mathrm{Q} 10$ & $\begin{array}{c}.13(\mathrm{Mgal} / \mathrm{d}) \\
/ \mathrm{mi}^{2} \mathrm{c}\end{array}$ & $\begin{array}{l}\text { 95-percent } \\
\text { flow duration }\end{array}$ & $\begin{array}{l}\text { 99-percent } \\
\text { flow duration }\end{array}$ & $\begin{array}{l}\text { 95-percent } \\
\text { flow duration }\end{array}$ & $\begin{array}{l}\text { 99-percent } \\
\text { flow duration }\end{array}$ & $7 \mathrm{Q} 10^{\mathrm{b}}$ & $.13 \underset{/ \mathrm{mi}^{2}}{(\mathrm{Mgal} / \mathrm{d})}$ & $\begin{array}{l}\text { 95-percent } \\
\text { flow duration }\end{array}$ & $\begin{array}{l}\text { 99-percent } \\
\text { flow duration }\end{array}$ & $\begin{array}{l}\text { 95-percent } \\
\text { flow duration }\end{array}$ & $\begin{array}{l}\text { 99-percent } \\
\text { flow duration }\end{array}$ \\
\hline (1) & (2) & (3) & (4) & (5) & (6) & $(7)$ & (8) & (9) & (10) & (11) & (12) & (13) \\
\hline 1. Cedar Swamp & 0.81 & 1.87 & 0.07 & $\cdot$ & - & - & $\cdot$ & $\cdot$ & - & - & - & - \\
\hline 2. Weston Pond & 1.57 & 2.24 & .42 & - & - & - & - & - & - & - & - & - \\
\hline 3. Mine Brook & 1.85 & 1.82 & .42 & - & 0.45 & - & - & - & - & - & - & - \\
\hline 4. Lake Pearl & 1.91 & 1.78 & .53 & - & .66 & - & - & - & - & - & - & - \\
\hline 5. Bellingham/Medway & 9.43 & 10.8 & .94 & - & 1.10 & - & - & 10.8 & - & - & 4.00 & 0.20 \\
\hline 6. Mirror Lake & 2.18 & 1.65 & .76 & - & 1.29 & 0.36 & - & - & - & - & - & - \\
\hline 7. Bogastow Brook & 3.36 & 3.02 & 1.06 & - & 1.40 & - & - & - & - & - & - & $\cdot$ \\
\hline 8. Millis/Medfield & 19.1 & 18.1 & 1.56 & 0.17 & 3.07 & 1.68 & - & - & - & - & - & - \\
\hline 9. Sherborn/Farm Pond & 20.8 & 20.1 & .38 & - & .06 & - & - & - & - & - & - & - \\
\hline 10. Morse's Pond/Elm Bank & 25.2 & 23.6 & 1.44 & - & 2.44 & .61 & 8.34 & 23.6 & 10.8 & 1.96 & - & - \\
\hline 11. Needham/Rock Meadow & 25.7 & 24.7 & .09 & - & - & - & - & - & - & - & - & - \\
\hline 12. Cutler Park & 28.4 & 27.2 & .74 & - & .88 & $\cdot$ & 6.66 & 27.2 & 10.9 & 2.06 & - & - \\
\hline 13. Rosemary Brook & .53 & .50 & .15 & - & .18 & - & - & - & - & - & - & - \\
\hline 14. Stony Brook & 1.06 & 1.98 & .37 & - & - & - & - & - & - & - & - & - \\
\hline 15. Newton/Waltham & 31.7 & 31.2 & .31 & - & .05 & - & 9.24 & 31.2 & 7.16 & - & - & - \\
\hline
\end{tabular}

${ }^{a}$ Assumes full development of yield in upstream reaches. Yields are not adjusted for current usage.

b Actual 7Q10s taken from table 2.

c Target flow of 0.2 cubic feet per second per square mile of drainage area ( 0.12924 million gallons per day per square mile). 
5. Flow is not artificially controlled during lowflow periods.

6. The stream does not drain an area that is heavily urbanized.

The regression equation that was developed by Cervione and others (1982) and that was used in this study is: $7 \mathrm{Q} 10=\left(0.67 \mathrm{~A}_{\mathrm{sd}}\right)+\left(0.01 \mathrm{~A}_{\text {till }}\right)$, where the 7Q10 low flow is in cubic feet per second; $\mathrm{A}_{s \mathrm{~d}}$ is the drainage area underlain by coarse-grained stratified drift, in square miles; and $\mathrm{A}_{\text {till }}$ is the drainage area underlain by tillmantled bedrock, in square miles, computed for the entire basin upstream from the furthest downstream point in the aquifer. Estimated 7Q10 low flows are converted to millions of gallons per day in column 4 , table 5 . Estimates of stream gains of $0.2\left(\mathrm{ft}^{3} / \mathrm{s}\right) / \mathrm{mi}^{2}$ were calculated from the drainage areas of the aquifers, and are listed in column 3 of table 5 in $\mathrm{Mgal} / \mathrm{d} / \mathrm{mi}^{2}$. The yield available at 95 and 99-percent flow duration when the target streamflows are maintained at the 7Q10 and $0.2\left(\mathrm{ft}^{3} / \mathrm{s}\right) / \mathrm{mi}^{2}$ levels, listed in columns 4-7 of table 5 , were determined by subtraction of the target minimum streamflows (columns 2 and 3 of table 5 minus upstream targets) from aquifer yields (columns 10 and 11 from table 4). For the 95-percent flow duration, only three of the 15 aquifers, Bogastow Brook, Millis/Medfield, and Morse's Pond/Elm Bank, are likely to yield more than $1 \mathrm{Mgal} / \mathrm{d}$ with minimum streamflows maintained at or above 7Q10 flows. However, with required stream gains of at least $0.2\left(\mathrm{ft}^{3} / \mathrm{s}\right) / \mathrm{mi}^{2}$ of drainage area, two aquifers, Bellingham/Medway and Mirror Lake, could yield $1 \mathrm{Mgal} / \mathrm{d}$ and be added to the three aquifers listed above.

Yields may also be available from induced infiltration of streamflow that enters the upstream end of the aquifers. These yields would only be available if some of the yields in excess of the target maintenance levels for aquifers upstream are not intercepted by wells in those aquifers. For example, nine aquifers are upstream from the Morse's Pond/Elm Bank aquifer. The total yield from these nine aquifers when the $7 \mathrm{Q} 10$ is maintained is $6.14 \mathrm{Mgal} / \mathrm{d}$. This value was obtained by summing the individual estimates of yield in column 4 of table 5 for the nine upstream aquifers, and assumes natural flow conditions. If any of this yield is not intercepted by wells upstream, then it would then be available for induced infiltration to wells in the Morse's Pond/Elm Bank aquifer.
Columns 8 and 9 of table 5 contain the target maintenance level streamflows at the downstream ends of 4 of the aquifers in the Charles River basin where gaging stations were located. The 7Q10 values in column 8 are computed from the measured streamflows at the gaging stations. The values in column 9 are the same as those in column 3 for the 4 gaging stations. A 7Q10 value has not been computed for the gaging station at the downstream end of the Bellingham/Medway aquifer (Charles River near Millis, station number 01103305) because the gaging station was operated for less than the 10 years required to accurately estimate the statistic. Yields listed in columns 10-13 of table 5 were computed by subtracting the target maintenance levels listed in columns 8 and 9 of table 5 from the actual yields at the gaging stations, listed in columns 12 and 13 of table 4. The actual yields with maintained streamflows can be compared to the estimated natural yields with maintained streamflows by summing the estimated natural yields in columns 4-7 for all aquifers upstream from, and including, the aquifer in which the gaging station is located.

\section{Yields to Individual Wells}

Estimates of aquifer yield are likely to be higher than the total yield of developed wells in the aquifer. Whereas aquifer yield is estimated for the entire area of an aquifer, useful well yield is controlled by factors such as well design, proximity to and size of surface-water sources, size of the upgradient drainage area, hydraulic properties of the aquifer, interference from other wells, restrictive land uses, and local surface-water and ground-water contamination.

The highest well yields in stratified-drift aquifers can be obtained where wells have small drawdowns and good hydraulic connection with large bodies of surface water. Lower yields are expected where well interference or areas of low transmissivity, such as silt, clay, till, or unfractured bedrock, cause drawdowns to increase (fig. 13). The amount of well interference depends on the hydraulic properties of an aquifer, the pumping rates of wells, the direction of regional ground-water flow, and the distance between wells. Drawdown would be greater if there were a fairly impermeable boundary, such as till or unfractured bedrock, within the area influenced by a well because ground-water flow would be restricted from the direction of the boundary. On the other hand, drawdown would be 


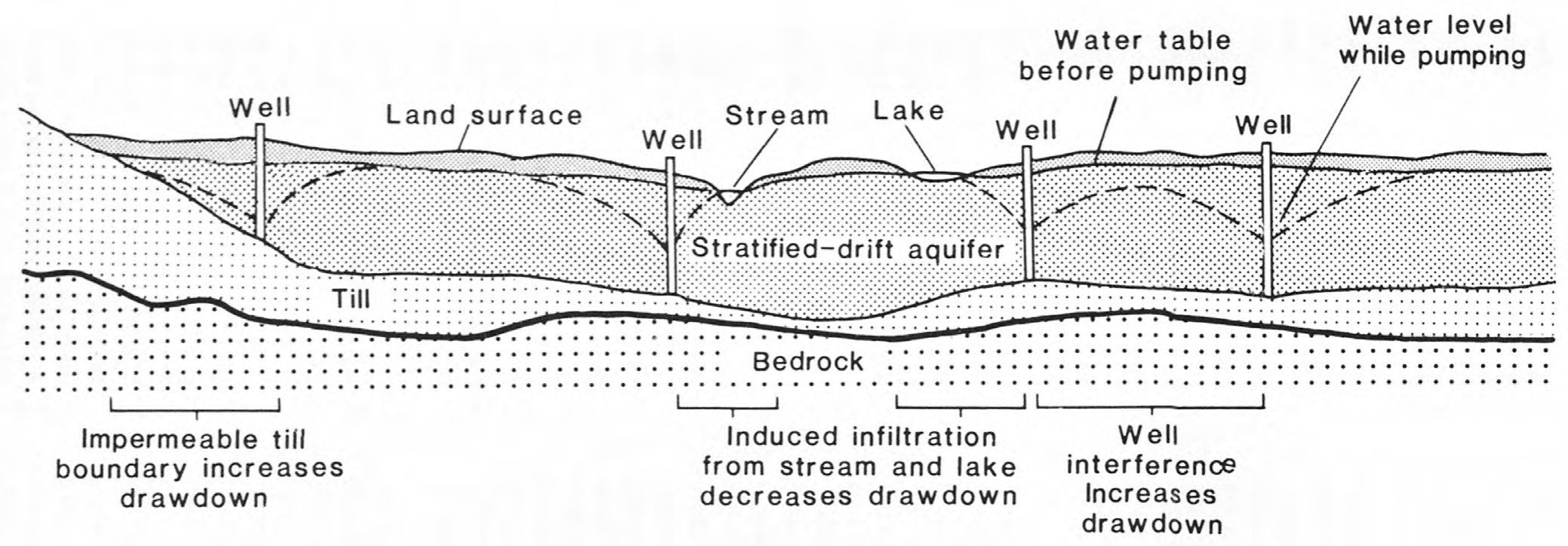

NOT TO SCALE

Figure 13.--Effects of hydrologic and geologic boundaries and well interference on drawdowns of water levels. 
less if a recharge source, a stream with a permeable streambed, were within the contributing area to a well.

In general, the amount of drawdown in a well depends on the pumping rate, the length of time that the well has been pumped, and the transmissivity of the aquifer. For example, using the Theis (1935) solution, a well pumping $300 \mathrm{gal} / \mathrm{min}$ for 30 days in an aquifer with a transmissivity of $5,000 \mathrm{ft}^{2} / \mathrm{d}$ will produce a drawdown of $5 \mathrm{ft}$ at a distance of $100 \mathrm{ft}$ from the pumped well (fig. 14). However, the Theis solution, which is a graphical procedure for evaluating the transmissivity and storage coefficient of confined aquifers, does not strictly apply to unconfined aquifers such as those in the Charles River basin. Therefore, drawdowns were adjusted using a method suggested by Jacob (1944) (fig. 15). Drawdown in a well that is affected by another pumped well can be estimated by adding the drawdowns at the wells (Reilly, 1987).

The yield of a well can be estimated from the transmissivity and saturated thickness of the aquifer. The method is based on the Theis equation, as modified by Jacob (1963) to apply to unconfined aquifers such as those in the Charles River basin. The method is based on several assumptions:

1. Wells have large diameters, are 100-percent efficient, and tap the entire saturated thickness of each aquifer.

2. Drawdown after 30 days of pumping is equal to two-thirds of the original saturated thickness.

3. Interference from other wells and hydraulic boundaries is negligible.

4. The specific yield of the aquifer is 0.20 .

The use of this technique is shown by two examples plotted in figure 16. In the first example, a well developed in a $60-\mathrm{ft}$ thick aquifer with a transmissivity of $15,000 \mathrm{ft}^{2} / \mathrm{d}$ could yield about $900 \mathrm{gal} / \mathrm{min}$. In the second example, the aquifer is only 15 -feet thick, the transmissivity is $6,000 \mathrm{ft}^{2} / \mathrm{d}$, and the estimated well yield is only about $100 \mathrm{gal} / \mathrm{min}$.

The potential yields of individual wells in the upper and middle Charles River basin range from less than $5 \mathrm{gal} / \mathrm{min}$ in areas that have low transmissivity and thin saturated zones to more than $2,500 \mathrm{gal} / \mathrm{min}$ in areas that have high transmissivity and thick saturated zones, such as near Newton and Waltham. About 5 percent of the basin area probably could support individual wells that yield $250 \mathrm{gal} / \mathrm{min}$ and about 2 percent of the basin probably could support wells that yield about $500 \mathrm{gal} / \mathrm{min}$. However, accurate estimates of well yield require specific information about well sites and should be verified by long-term pumping tests.

\section{PREDICTED EFFECTS OF GROUND- WATER DEVELOPMENT ON THE CHARLES RIVER}

One method of evaluating development proposals for the middle and upper Charles River basin is to use a computer model that simulates the hydrology and water-supply system of the basin. A streamflow-accounting model designed by Burns. and James (1972) to simulate development of aquifers in the Ipswich River basin in northeastern Massachusetts was used in the middle and upper Charles River basin. This model was designed to be as general as possible so that it could be used in other basins. However, because the model simulates the response of streamflow to pumpage from wells, its use requires that a basin contain aquifers that are hydraulically connected to a river. The middle and upper Charles River basin meets this requirement of the model because most public supply wells in the basin are located near the Charles River and derive most of their water from the river.

Hydrologic input for the model was mean monthly streamflows from January 1969 through December 1978 for streamflow-gaging stations along the Charles River at Dover, Wellesley, and Waltham and from August 1974 through September 1980 for the streamflow-gaging station at Millis (fig. 17). Streamflow during this period was relatively normal, as it did not include the largest floods of record (August 1955 and March 1968) or a severe drought, such as that which occurred in the mid-1960s.

The basin was divided into 34 subbasins that were identified by points on the river called nodes. Features of the water-supply systems, which include tributaries, reservoirs, points of diversion, wells, streamflow-gaging stations, and towns, were assigned to subbasins in downstream order so that the effects of any upstream activity would be reflected in the downstream flow (fig. 18). A subbasin could contain up to nine wells, but only one of each of the other types of features. In total, the 34 subbasins represented 26 towns that depend on the water resources of the basin; four reservoirs (Echo Lake, Sandy Pond, Cambridge Reservoir, and Stony Brook); one diversion of water out of the basin (Mother Brook); four tributaries (Stop River, 


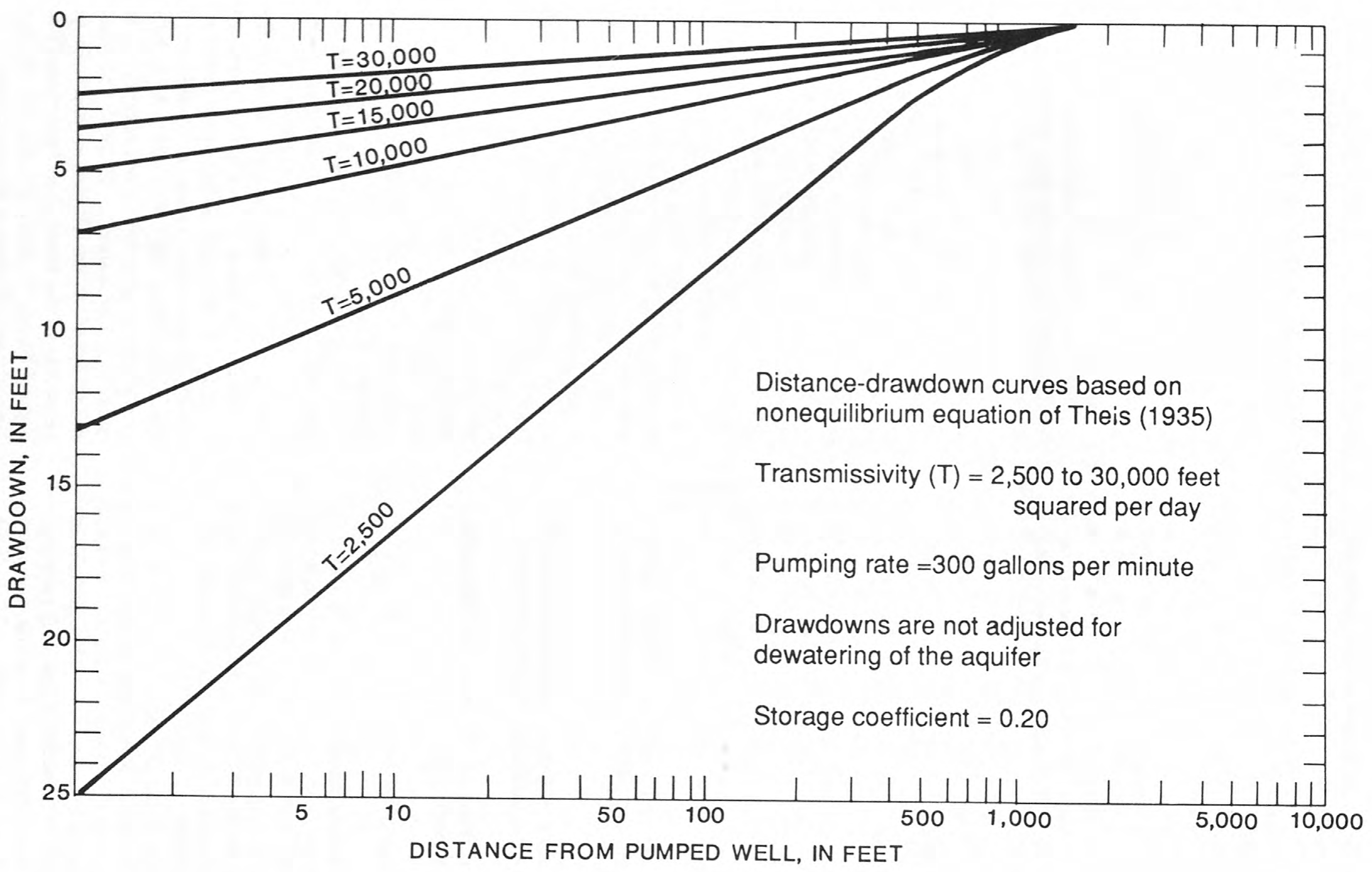

Figure 14.--Theoretical relation between transmissivity, drawdown, and distance from a well at the end of continuous pumping for 30 days at 300 gallons per minute. [From Reeder, 1972, fig. 9.] 


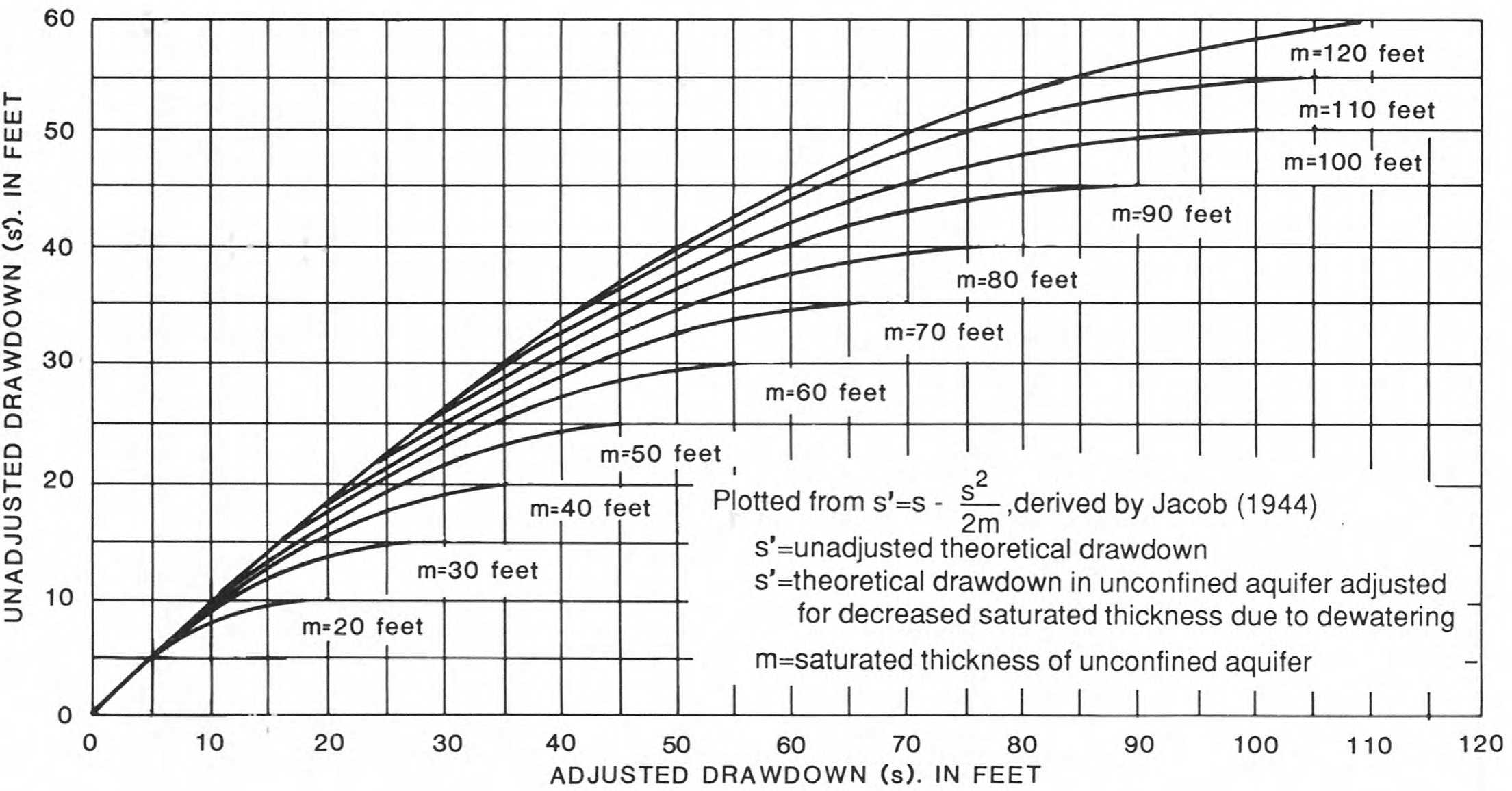

Figure 15.--Theoretical curves for adjustment of drawdown data from figure 15 to compensate for dewatering of a water-table aquifer. [From Reeder, 1972, fig. 10.] 


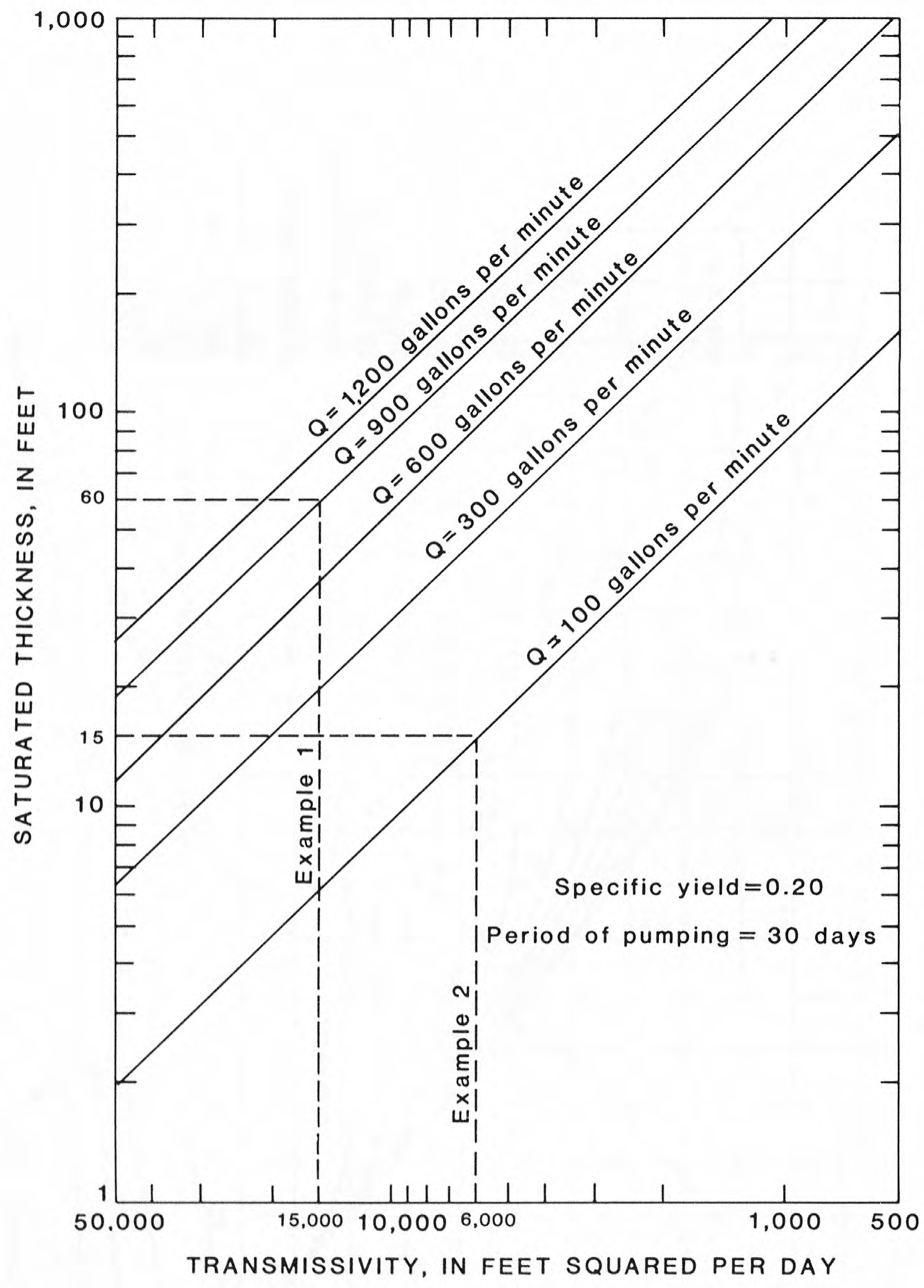

Figure 16.--Theoretical relation between transmissivity, saturated thickness, and maximum yield of wells in stratified-drift aquifers. [From Reeder, 1972, fig. 7.] 


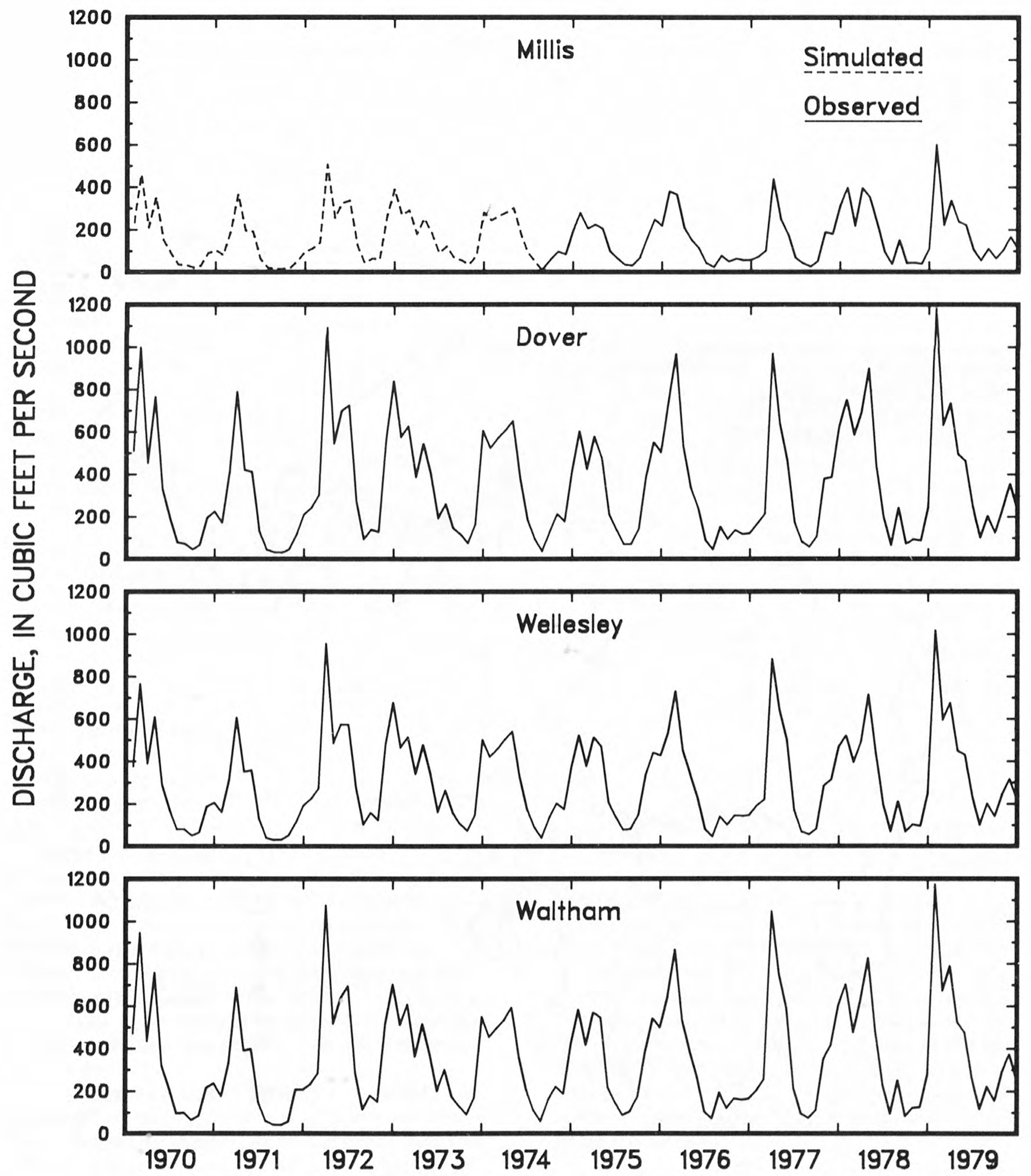

Figure 17.--Observed and simulated streamflow in the Charles River at four U.S. Geological Survey streamflow-gaging stations, 1969-78. 


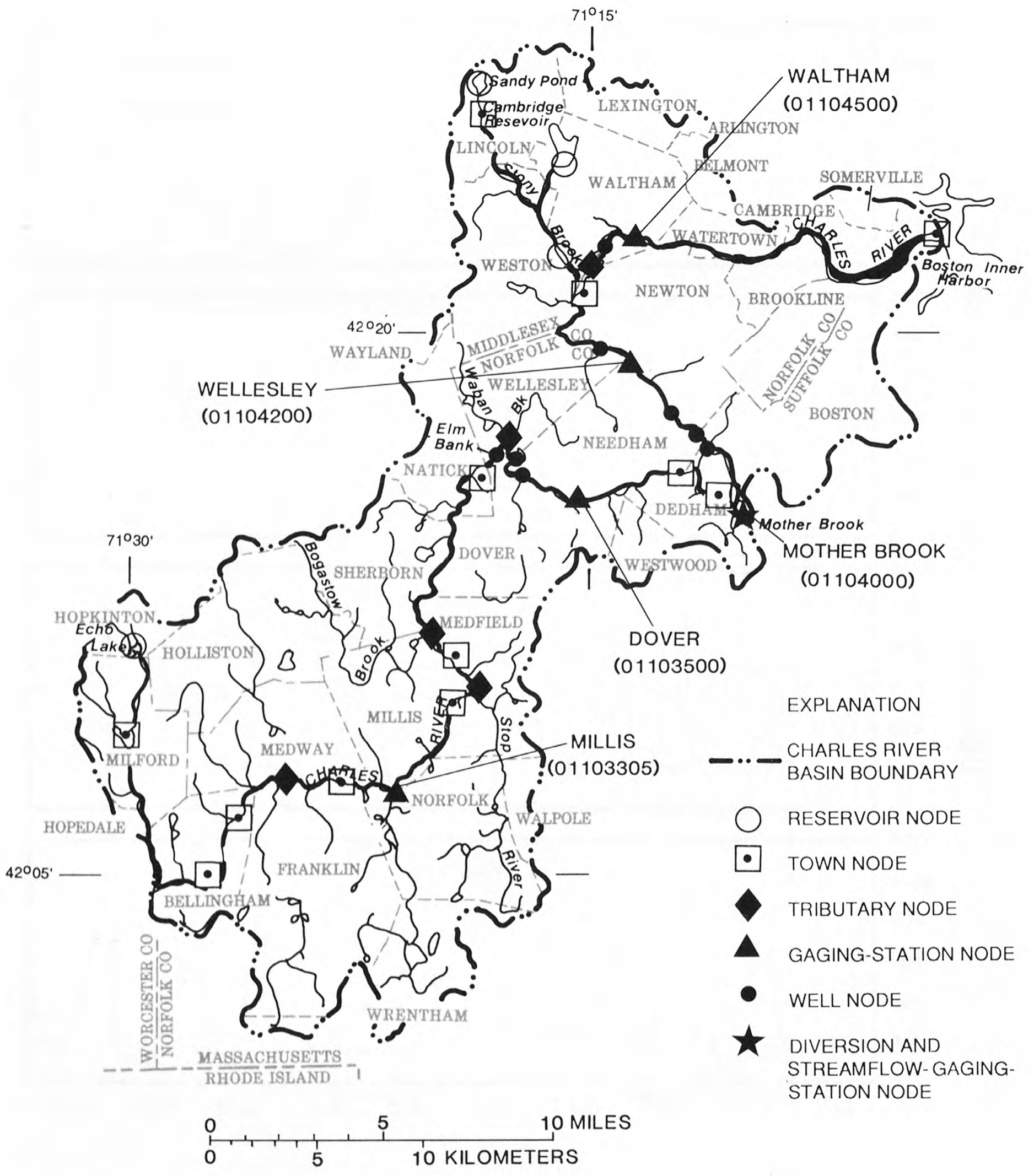

Figure 18.--Location of features simulated in the streamflow-accounting model. 
Bogastow Brook, Waban Brook, and Stony Brook); four U.S. Geological Survey streamflow-gaging stations (Millis, Dover, Wellesley, and Waltham); and one MWRA out-of-basin source (reservoirs in the Chicopee and Nashua River basins) (fig. 19).

Modeling of the current or an alternative waterdevelopment system requires that the model perform specific functions on subsets of nodes. Existing operating rules are observed; for example, no diversions are allowed below minimum streamflows.

The first iteration distributes the first month's mean streamflows at the streamflow-gaging stations to each subbasin. The next iteration accounts for streamflow depletion resulting from ground-water withdrawals. Streamflow depletion is computed using a method developed by Jenkins (1968). This method considers well pumpage, distance of the well from the stream, and transmissivity and specific yield of the aquifer. No distinction is made between streamflow depletion which results when wells intercept ground water flowing to a river and that which results when water is induced by pumping to flow from a river to wells. To simulate seasonal recharge to aquifers, an event that usually occurs from late winter to early spring in New England, streamflowdepletion effects are reset to zero at the beginning of each year.

A third iteration attempts to satisfy each town's water demand using existing supply sources, including wells, streamflow diversions, and reservoir withdrawals. These sources are used in order of priority until they are depleted or until demand is satisfied. Any unsatisfied demand is carried over to the next iteration. For the Charles River basin, where a town is not connected to the MWRA sewer system, a portion of water used by each town is returned as streamflow. This amount can be varied each month to account for monthly evapotranspiration losses. The return fraction for towns that have MWRA sewer connections was zero; fractions for Franklin, Holliston, Lincoln, Medfield, Medway, Milford, Millis, and Norfolk, towns that rely on septic systems or treatment plants, ranged from about 70 percent during the summer to almost 100 percent during the winter.

A fourth iteration attempts to satisfy any demands not met by existing supply sources from a set of proposed sources, including wells, reservoir withdrawals, and purchases of water from out-ofbasin sources. The model then diverts streamflow to reservoirs, and, finally, diverts water from one reservoir to another. After completion of these operations, the next month's mean monthly flows are read into the model and the sequence of operations is repeated. For the Charles River basin, the sequence was repeated 120 times, the number of months in the simulation period.

The model was used to simulate present and additional water-resources development in the middle and upper Charles River basin (table 6). Additional ground-water withdrawals of 11, 23, and $34 \mathrm{Mgal} / \mathrm{d}$ were simulated to demonstrate the effects of increased aquifer development on streamflow in the Charles River. However, the amount of streamflow depletion resulting from increased development will vary according to the demands, reservoir withdrawals and transfers, imports, and return flows to the river specified in the model.

For the water-supply systems modeled, results indicate that pumpage of $11 \mathrm{Mgal} / \mathrm{d}$ above present pumpage rates (option 2 in table 6) would reduce streamflow at Waltham about $6 \mathrm{ft}^{3} / \mathrm{s}(4 \mathrm{Mgal} / \mathrm{d})$ throughout the year. This reduction would reduce streamflow at this location to zero at the 99 -percent flow duration (table 2), which occurs an average of four days per year. Pumpage and subsequent export of $23 \mathrm{Mgal} / \mathrm{d}$ of water above present pumpage rates (option 3 in table 6) would reduce streamflow at Waltham about $14 \mathrm{ft}^{3} / \mathrm{s}$ (9 Mgal/d) throughout the year. Again, streamflow at Waltham would be zero at the 99-percent flow duration. Finally, pumpage of $34 \mathrm{Mgal} / \mathrm{d}$ above present pumpage rates, with export of $23 \mathrm{Mgal} / \mathrm{d}$, (option 4 in table 6) would reduce streamflow at Waltham about $26 \mathrm{ft}^{3} / \mathrm{s}(17 \mathrm{Mgal} / \mathrm{d})$. This last reduction would deplete flow in the Charles River at Waltham to zero at the 95-percent flow duration (table 2), which occurs an average of 18 days per year.

At the 95-percent flow duration, simulated streamflows show that increased development of the basin's water resources may cause some stream reaches that previously gained flow at downstream points to show losses (fig. 20). Flow-duration curves for the Charles River at Waltham, developed from streamflows simulated by the model, show reductions in streamflow that may result from increased development (fig. 21). For some periods of low flow, the curves indicate a cessation of flow in the river near the Waltham gage. Table 7 shows the percentage of time that simulated streamflows in the Charles River at Waltham equaled or exceeded selected minimum streamflows.

Simulated streamflows at the 95-percent flow duration at four different development options (table 8) and at stream locations from southern Natick to the Dover streamflow-gaging station are shown in figure 22. Flow-duration curves for the Charles River at Dover, which were developed from 
NODE LOCATION

1. ECHO LAKE

2. MILFORD

3. BELLINGHAM

4. NORTH BELLINGHAM

5. WEST MEDWAY, FRANKLIN AND HOLLISTON

6. MEDWAY

7. MILLIS GAGE

8. MILLIS

9. WALPOLE

10. HOLLISTON

11. MEDFIELD

12. SOUTH NATICK

13. DOVER (ELM BANK)

14. MORSES' POND

15. WELLESLEY

16. NEEDHAM (SOUTHWEST)

17. DOVER GAGE

18. NEEDHAM

19. DEDHAM

20. MOTHER BROOK

21. CUTLER PARK (SOUTHWEST)

22. NEWTON (CUTLER PARK)

23. CUTLER PARK (NORTHWEST)

24. WELLESLEY GAGE

25. ROSEMARY BROOK

26. WESTON

27. STONY BROOK

28. STONY BROOK RESERVOIR

29. CAMBRIDGE RESERVOIR

30. LINCOLN

31. SANDY POND RESERVOIR

32. WALTHAM

33. WALTHAM GAGE

34. BOSTON HARBOR

\section{FEATURE}

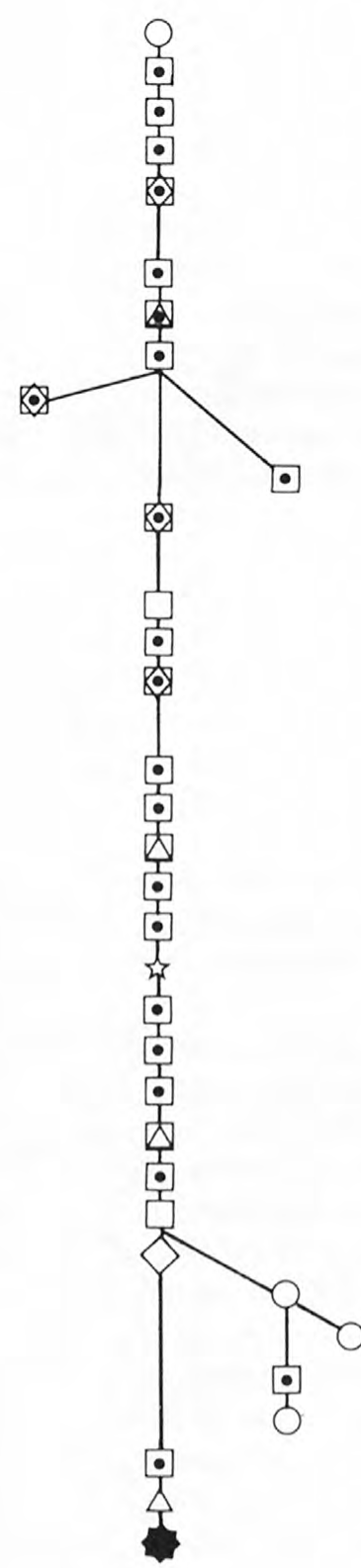

RESERVOIR

TOWN, WELLS

TOWN, WELLS

TOWN, WELLS

TOWN, WELLS,

AND TRIBUTARY

TOWN, WELLS

TOWN, WELLS, GAGE

TOWN, WELLS

TOWN, WELLS

AND TRIBUTARY

TOWN, WELLS

TOWN, WELLS,

AND TRIBUTARY

TOWN

TOWN, WELLS

TOWN, WELLS

AND TRIBUTARY

TOWN, WELLS

TOWN, WELLS

TOWN, GAGE

TOWN, WELLS

TOWN, WELLS

DIVERSION, GAGE

TOWN, WELLS

TOWN, WELLS

TOWN, WELLS

TOWN, GAGE

TOWN, WELLS

TOWN

TRIBUTARY

RESERVOIR

RESERVOIR

TOWN, WELLS

RESERVOIR

TOWN, WELLS

GAGE

MWRA WATER AND

SEWER SYSTEMS

\section{EXPLANATION}

$\begin{array}{ll}\bullet & \text { Well } \\ \square & \text { Reservoir } \\ & \text { Town } \\ & \text { Diversion and gage } \\ \text { Tributary } \\ \text { MWRA (Massachusetts } \\ \text { Water Resources Authority) }\end{array}$

Figure 19.--Nodes and features simulated in the streamflow-accounting model. 
Table 6.--Simulated development of water resources in the middle and upper Charles River basin and effects on streamflow at Waltham

[Mgal/d, million gallons per day; $\mathrm{ft}^{3} / \mathrm{s}$, cubic feet per second]

\begin{tabular}{|c|c|c|}
\hline Option & Development & Effect on streamflow \\
\hline 1 & $\begin{array}{l}66 \mathrm{Mgal} / \mathrm{d} \\
\text { (Present development) }\end{array}$ & Present streamflow \\
\hline 2 & $77 \mathrm{Mgal} / \mathrm{d}$ & $\begin{array}{l}\text { Streamflow reduction of } 6 \mathrm{ft}^{3} / \mathrm{s}(4 \mathrm{Mgal} / \mathrm{d}) \text { or a } \\
24 \text {-percent reduction in flow at the } 95 \text {-percent } \\
\text { flow duration }\end{array}$ \\
\hline 3 & $\begin{array}{l}89 \mathrm{Mgal} / \mathrm{d} \\
(23 \mathrm{Mgal} / \mathrm{d} \text { exported } \\
\text { from the basin) }\end{array}$ & $\begin{array}{l}\text { Streamflow reduction of } 14 \mathrm{ft}^{3} / \mathrm{s}(9 \mathrm{Mgal} / \mathrm{d}) \text { or a } \\
55 \text {-percent reduction in flow at the } 95 \text {-percent } \\
\text { flow duration }\end{array}$ \\
\hline 4 & $\begin{array}{l}100 \mathrm{Mgal} / \mathrm{d} \\
(23 \mathrm{Mgal} / \mathrm{d} \text { exported } \\
\text { from the basin) }\end{array}$ & $\begin{array}{l}\text { Streamflow reduction of } 26 \mathrm{ft}^{3} / \mathrm{s}(17 \mathrm{Mgal} / \mathrm{d}) \text { or } \\
\text { no flow at the } 95 \text {-percent flow duration }\end{array}$ \\
\hline
\end{tabular}

streamflows simulated by the model, show reductions in streamflow that may result from increased development of the Morse's Pond/Elm Bank aquifer (fig. 23). Table 9 shows the percentage of time that simulated streamflows in the Charles River at Dover equaled or exceeded selected minimum streamflows.

\section{SUMMARY}

This report describes municipal water use in the middle and upper Charles River basin for the period 1980-83 and gives estimates of yields for 15 stratified-drift aquifers in the basin.

In 1984, the amount of municipally supplied water used by towns in the middle and upper Charles River basin and by the city of Cambridge was about $66 \mathrm{Mgal} / \mathrm{d}$, about half of which came from surfacewater and ground-water sources within the basin. By the year 2020, an additional $11 \mathrm{Mgal} / \mathrm{d}$ may be needed. The largest sources of undeveloped water in the basin are 15 stratified-drift aquifers which cover about 30 percent of the middle and upper Charles River basin and are located along the river and tributary channels. These unconfined aquifers are composed mostly of medium to coarse sand and gravel and are underlain by till and bedrock. The depth of the water table is generally less than $15 \mathrm{ft}$ and the water table fluctuates from 3 to $5 \mathrm{ft}$ per year. The maximum thickness of the aquifers increases from about 40 to $100 \mathrm{ft}$ from the southwestern to the northeastern part of the basin. Aquifer transmissivity is as much as $25,000 \mathrm{ft}^{2} / \mathrm{d}$ in parts of the Newton/Waltham, Bellingham/Medway, Millis/Medfield, and Morse's Pond/Elm Bank aquifers.

Ground water, mostly derived from precipitation and ground water from adjacent till and bedrock, moves through the aquifers and discharges to the Charles River and its tributaries. Groundwater discharge at the Waltham streamflow-gaging station during an average year is estimated to be about $20 \mathrm{Mgal} / \mathrm{d}$, the flow exceeded 95 percent of the time.

Long-term sustainable yields of the 15 aquifers were estimated by considering water that is available from intercepted ground-water discharge and induced infiltration from streams. Flow-duration curves were developed for the largest stream draining each aquifer. The 95- and 99-percent flow durations on these curves provided estimates of yields available from intercepted ground-water discharge. Yields available from this source range from about $0.6 \mathrm{Mgal} / \mathrm{d}$ from the Needham/Rock Meadow aquifer to about $5.8 \mathrm{Mgal} / \mathrm{d}$ from the Morse's Pond/Elm Bank aquifer at the 95-percent flow duration. Although large amounts of water potentially 


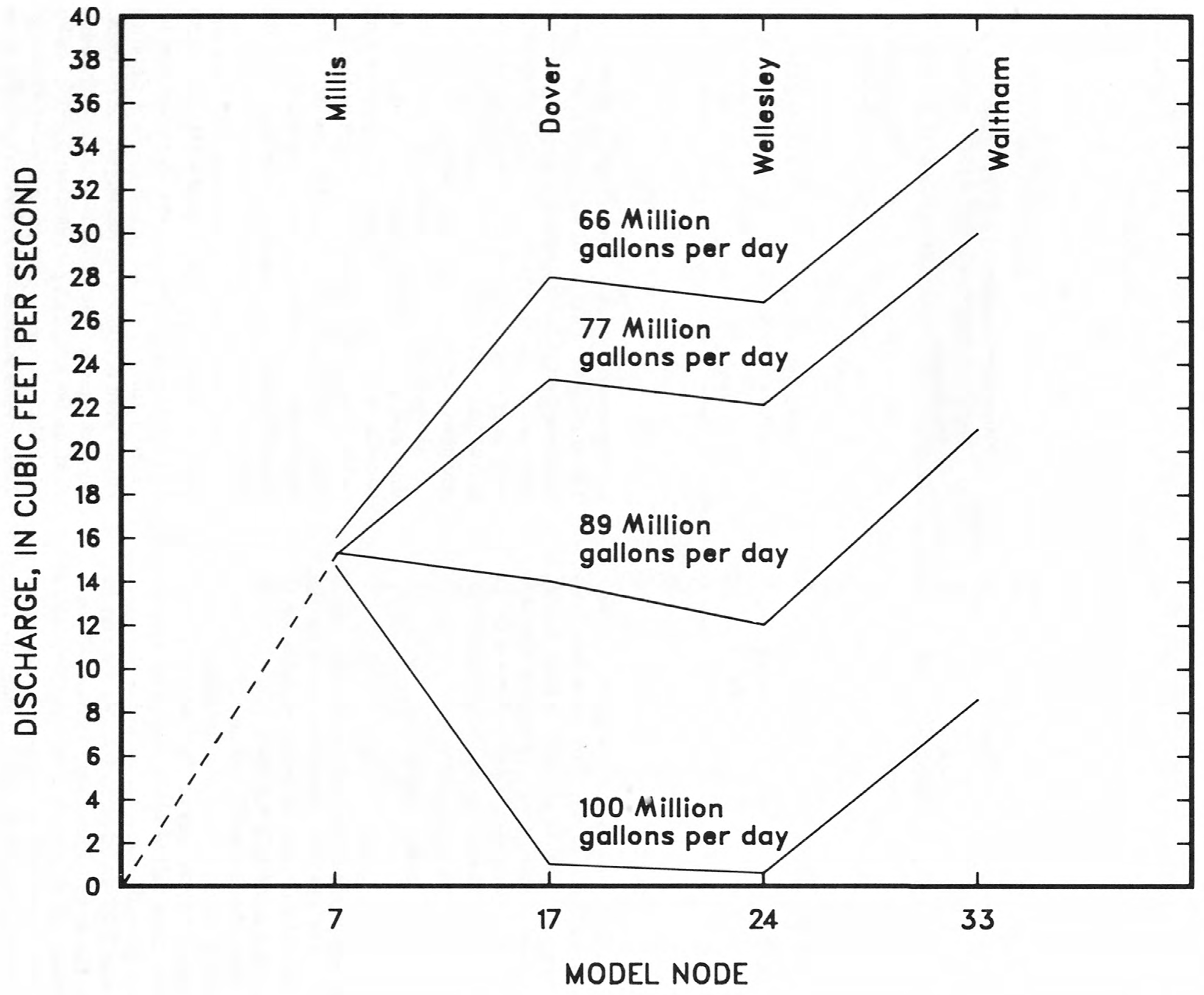

Figure 20.--Simulated streamflow at the 95-percent flow duration for four U.S. Geological Survey streamflow-gaging stations in the Charles River basin. 


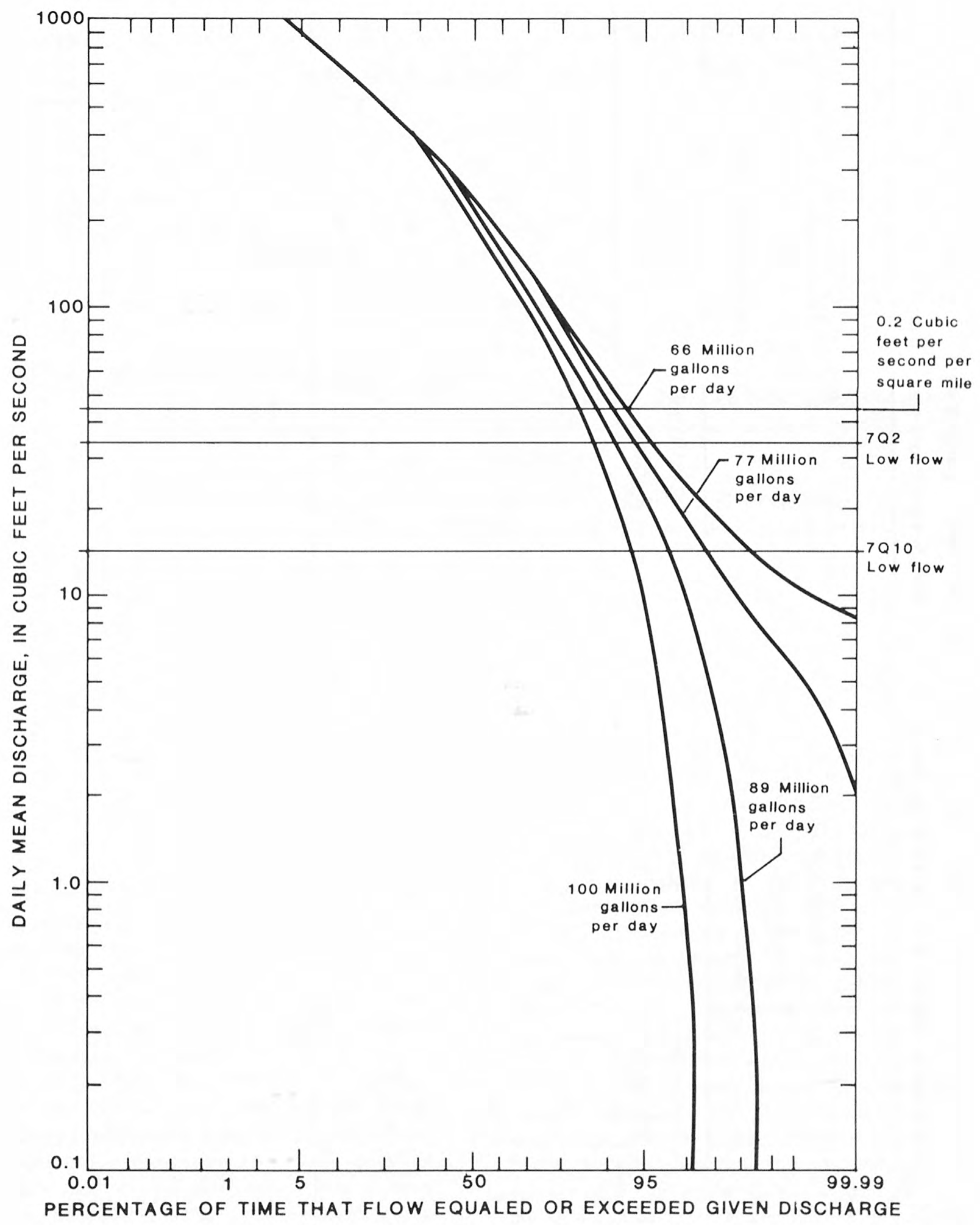

Figure 21.--Flow-duration curves of the Charles River at Waltham for ground-water pumpage of $66,77,89$ and 100 million gallons per day. 
Table 7.--Percentage of time that simulated streamflows in the Charles River at Waltham equaled or exceeded minimum streamflows [Mgal/d, million gallons per day; $\mathrm{ft}^{3} / \mathrm{s}$, cubic feet per second; $\left(\mathrm{ft}^{3} / \mathrm{s}\right) / \mathrm{mi}^{2}$, cubic feet per second per square mile of drainage area]

\begin{tabular}{|c|c|c|c|c|c|c|c|}
\hline & \multirow[t]{2}{*}{ Option } & \multicolumn{3}{|c|}{$\begin{array}{c}\text { Average hydrologic } \\
\text { conditions (1969-79) } \\
\text { Minimum streamflow criteria }\end{array}$} & \multicolumn{3}{|c|}{$\begin{array}{l}\text { Drought conditions } \\
\qquad(1966)\end{array}$} \\
\hline & & $\begin{array}{c}0.2\left(\mathrm{ft}^{3} / \mathrm{s}\right) / \mathrm{mi}^{2} \\
\left(45.4 \mathrm{ft}^{3} / \mathrm{s}\right)\end{array}$ & $\begin{array}{c}7 \mathrm{Q} 2 \\
\left(34.0 \mathrm{ft}^{3} / \mathrm{s}\right)\end{array}$ & $\begin{array}{c}7 \mathrm{Q} 10 \\
\left(14.3 \mathrm{ft}^{3} / \mathrm{s}\right)\end{array}$ & $\begin{array}{c}0.2\left(\mathrm{ft}^{3} / \mathrm{s}\right) / \mathrm{mi}^{2} \\
\left(45.4 \mathrm{ft}^{3} / \mathrm{s}\right)\end{array}$ & $\begin{array}{c}7 \mathrm{Q} 2 \\
\left(34.0 \mathrm{ft}^{3} / \mathrm{s}\right)\end{array}$ & $\begin{array}{c}7 \mathrm{Q} 10 \\
\left(14.3 \mathrm{ft}^{3} / \mathrm{s}\right)\end{array}$ \\
\hline 1. & $66 \mathrm{Mgal} / \mathrm{d}$ & 92 & 95 & 99.5 & 63 & 70 & 94 \\
\hline 2. & $77 \mathrm{Mgal} / \mathrm{d}$ & 90 & 93 & 99.5 & 58 & 65 & 94 \\
\hline 3. & $89 \mathrm{Mgal} / \mathrm{d}$ & 87 & 91 & 97 & 54 & 61 & 80 \\
\hline 4. & $100 \mathrm{Mgal} / \mathrm{d}$ & 84 & 87 & 93 & 41 & 54 & 65 \\
\hline
\end{tabular}


[Mgal/d, million gallons per day; $\mathrm{ft}^{3} / \mathrm{s}$, cubic feet per second]

Option Development Effect on streamflow

1

5 wells, $4 \mathrm{Mgal} / \mathrm{d}$

(Present development)

2

9 wells, $7 \mathrm{Mgal} / \mathrm{d}$

3

4

9 wells, $13 \mathrm{Mgal} / \mathrm{d}$

(6 Mgal/d exported)
Present streamflow

Streamflow reduction of $4.6 \mathrm{ft}^{3} / \mathrm{s}(3.0 \mathrm{Mgal} / \mathrm{d})$ or a 16-percent reduction in flow at the 95 -percent flow duration

Streamflow reduction of $9 \mathrm{ft}^{3} / \mathrm{s}(6 \mathrm{Mgal} / \mathrm{d})$ or a 30 -percent reduction in flow at the 95 -percent flow duration

Streamflow reduction of $12 \mathrm{ft}^{3} / \mathrm{s}(8 \mathrm{Mgal} / \mathrm{d})$ or a 40 -percent reduction in flow at the 95 -percent flow duration are available from aquifers in the middle and upper basin, additional pumpage will reduce flow in the Charles River and its tributaries at some locations. Therefore, yields available from intercepted ground-water discharge were adjusted to meet commonly cited minimum-streamflow criteria. Only three aquifers, Bogastow Brook, Millis/Medfield, and Morse's Pond/Elm Bank, are likely to yield more than $1 \mathrm{Mgal} / \mathrm{d}$ from intercepted ground-water discharge with streams maintained at or above 7-day, 10-year low-flow levels for 95 percent of the time. If minimum stream gains are set at $0.2\left(\mathrm{ft}^{3} / \mathrm{s}\right) / \mathrm{mi}^{2}$ of drainage area, two aquifers, Mirror Lake and Bellingham/Medway, could be added to the three aquifers listed above.

Water also is available to wells from streamflow that enters the upstream end of each aquifer. Yields from induced infiltration from the Charles River were estimated for four aquifers for which sufficient streamflow data were available, and range from about 4 to $11 \mathrm{Mgal} / \mathrm{d}$ at the 95 -percent flow duration. If minimum-streamflow criteria are also to be maintained, these yield estimates would be substantially lower.

The yield estimates given in this report may be useful in assessing the potential of an aquifer to sustain current or increased withdrawals during nor- mal and drought conditions, and in planning and managing the regional development of the water resources in the basin.

A streamflow-accounting model was used to simulate changes in streamflow resulting from increases in municipal-well withdrawals in the middle and upper Charles River basin. The model simulates well withdrawals, diversions, transfers of water from reservoirs, and imports and exports of water, and calculates the effects of these activities on monthly streamflow. According to the resuits of the model simulations, increasing pumping from 66 to $77 \mathrm{Mgal} / \mathrm{d}$ is likely to reduce streamflow at Waltham by about $6 \mathrm{ft}^{3} / \mathrm{s}(4 \mathrm{Mgal} / \mathrm{d})$. This would reduce streamflow at this location to zero at the 99-percent flow duration, which occurs about four days per year. A pumping rate of $100 \mathrm{Mgal} / \mathrm{d}$ would reduce streamflow at Waltham by about $26 \mathrm{ft}^{3} / \mathrm{s}(17 \mathrm{Mgal} / \mathrm{d})$. This would result in a cessation of flow in the Charles River at this location at the 95-percent flow duration, which occurs an average of 18 days per year. The streamflow-accounting model indicated that an increase in pumpage of $11 \mathrm{Mgal} / \mathrm{d}$ would reduce streamflow at Waltham by about $6 \mathrm{ft}^{3} / \mathrm{s}$ (4 Mgal/d) throughout the year. Also, model results indicate that an increase of pumpage and export as wastewater from the basin would reduce streamflow at Waltham by about $14 \mathrm{ft}^{3} / \mathrm{s}(9 \mathrm{Mgal} / \mathrm{d})$ throughout the year. 


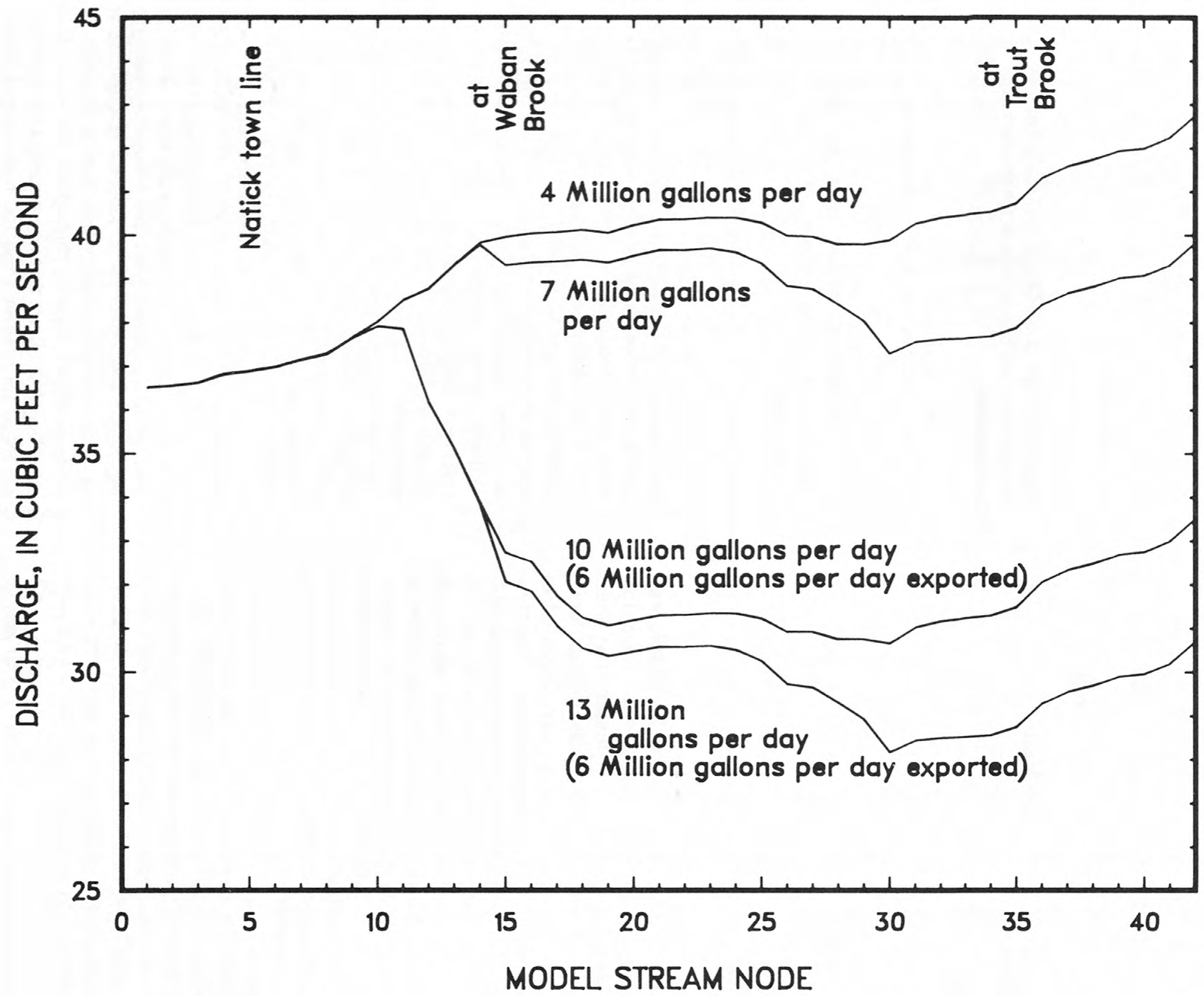

Figure 22.--Simulated streamflows at the 95-percent flow duration between southern Natick and Dover. 


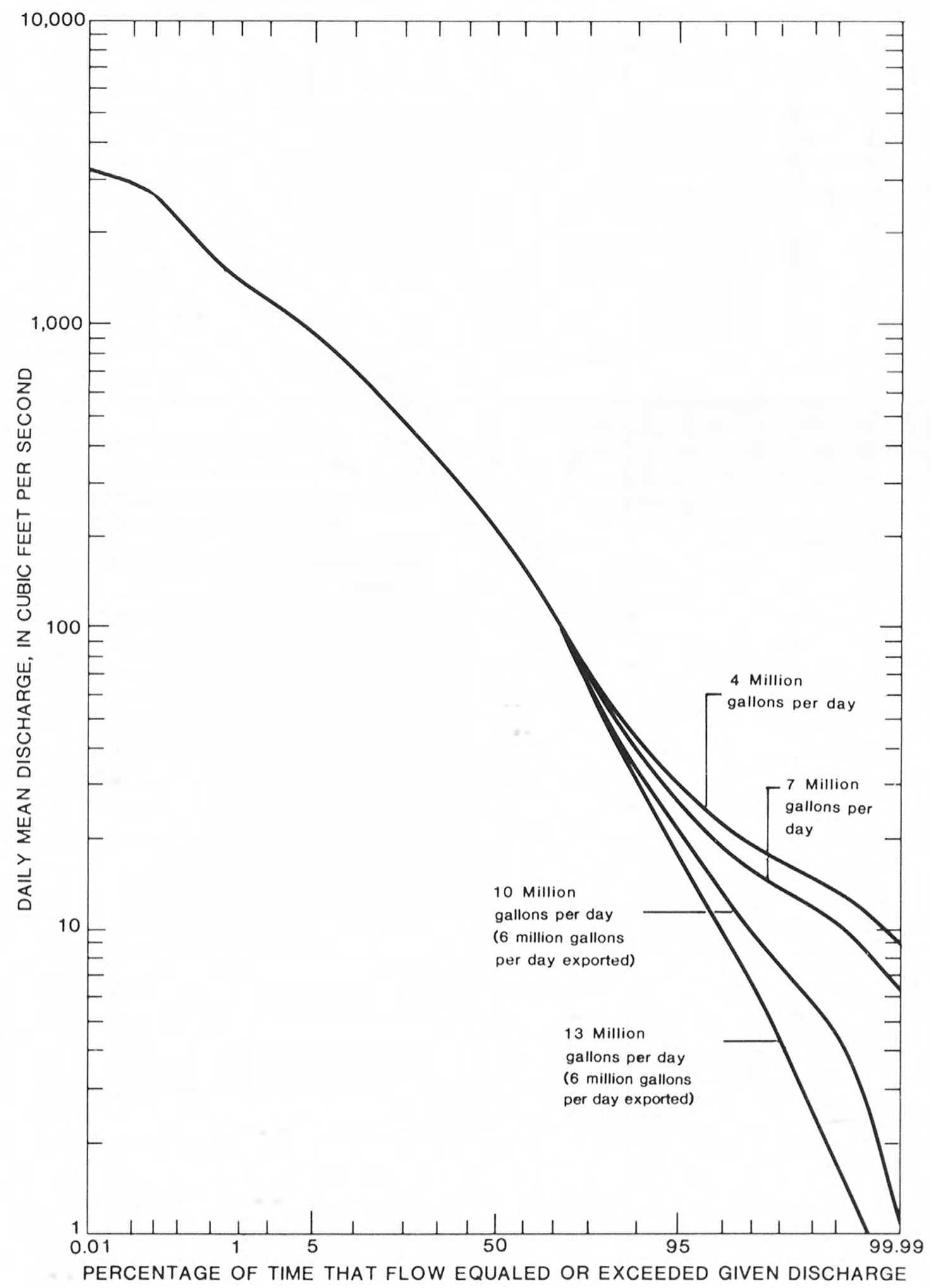

Figure 23.--Flow-duration curves of the Charles River at Dover resulting from alternative development of the Morse's Pond/Elm Bank aquifer at 4, 7, 10 and 13 million gallons per day. 
Table 9.--Percentage of time that streamflow in the Charles River at Dover equaled or exceeded minimum streamflows

[Mgal/d, million gallons per day; $\mathrm{ft}^{3} / \mathrm{s}$, cubic feet per second; $\left(\mathrm{ft}^{3} / \mathrm{s}\right) / \mathrm{mi}^{2}$, cubic feet per second per square mile of drainage area]

\begin{tabular}{|c|c|c|c|c|c|c|c|}
\hline & \multirow[b]{2}{*}{ Option } & \multicolumn{3}{|c|}{$\begin{array}{c}\text { Average hydrologic } \\
\text { conditions (1959-83) } \\
\text { Minimum streamflow criteria }\end{array}$} & \multicolumn{3}{|c|}{$\begin{array}{l}\text { Drought conditions } \\
\qquad(1966) \\
\text { Minimum streamflow criteria }\end{array}$} \\
\hline & & $\begin{array}{c}0.2\left(\mathrm{ft}^{3} / \mathrm{s}\right) / \mathrm{mi}^{2} \\
\left(36.6 \mathrm{ft}^{3} / \mathrm{s}\right)\end{array}$ & $\begin{array}{c}7 \mathrm{Q} 2 \\
\left(32.5 \mathrm{ft}^{3} / \mathrm{s}\right)\end{array}$ & $\begin{array}{c}7 \mathrm{Q} 10 \\
\left(12.9 \mathrm{ft}^{3} / \mathrm{s}\right)\end{array}$ & $\begin{array}{c}0.2\left(\mathrm{ft}^{3} / \mathrm{s}\right) / \mathrm{mi}^{2} \\
\left(36.6 \mathrm{ft}^{3} / \mathrm{s}\right)\end{array}$ & $\begin{array}{c}7 \mathrm{Q} 2 \\
\left(32.2 \mathrm{ft}^{3} / \mathrm{s}\right)\end{array}$ & $\begin{array}{c}7 \mathrm{Q} 10 \\
\left(12.9 \mathrm{ft}^{3} / \mathrm{s}\right)\end{array}$ \\
\hline 1. & $4 \mathrm{Mgal} / \mathrm{d}$ & 92 & 94 & 99.9 & 60 & 64 & 97 \\
\hline 2. & $7 \mathrm{Mgal} / \mathrm{d}$ & 91 & 92 & 99.6 & 59 & 60 & 93 \\
\hline 3. & $10 \mathrm{Mgal} / \mathrm{d}$ & 88 & 90 & 98 & 53 & 57 & 84 \\
\hline & $13 \mathrm{Mgal} / \mathrm{d}$ & 87 & 89 & 96 & 49 & 55 & 72 \\
\hline
\end{tabular}




\section{REFERENCES CITED}

Bell, K. G., 1948, Geology of the Boston metropolitan area: Cambridge, Massachusetts, Massachusetts Institute of Technology, unpublished Ph.D. dissertation, 390 p.

Burns, A. W., and James, I. C., II, 1972, Computer simulation of the Ipswich River basin: Massachusetts Water Resources Commission, 6317, p. 66.

Cervione, M. A., Jr., Mazzaferro, D. L., and Melvin, R. L., 1972, Water-resources inventory of Connecticut, part 6, upper Housatonic River basin: Connecticut Water Resources Bulletin 21, 84 p.

Cervione, M. A., Jr, Melvin, R. L., and Cyr, K. A., 1982, A method for estimating the 7-day, 10-year low flow of streams in Connecticut: Connecticut Water-Resources Bulletin no. 34, 17 p.

Dowse, A. M., 1949, Geology of the Medfield-Holliston area: Cambridge, Massachusetts, Harvard University, unpublished Ph.D. thesis, 133 p.

Fenneman, N. M., 1938, Physiography of Eastern United States: New York, McGraw-Hill Book Co., 714 p.

Ferris, J. G., Knowles, D. B., Brown, R. H., and Stallman, R. W., 1962, Theory of aquifer tests: U.S. Geological Survey Water-Supply Paper 1536-E, 106 p.

Frimpter, Michael H,, 1981, Probable high groundwater levels in Massachusetts: U.S. Geological Survey Water-Resources Investigations OpenFile Report 80-1205, 19 p.

Hall, Max, 1986, The Charles, the people's river: D.R. Godine, Boston, 108 p.

Jacob, C. E., 1944, Notes on determining permeability by pumping tests under water-table conditions: U.S. Geological Survey Open-file Report, 25 p.

1963, Determining the permeability of watertable aquifers, in Methods of determining permeability, transmissibility, and drawdown: U.S. Geological Survey Water-Supply Paper 1536-I, p. 272-292.

Jenkins, C. T., 1968, Computation of rate and volume of stream depletion by wells: U.S. Geological Survey, Techniques of Water-Resources Investigations, book 4, chap. D1, 17 p.
Johnson, A. I., 1967, Specific-yield compilation of specific yields for various materials: U.S. Geological Survey Water-Supply Paper 1662-D, $74 \mathrm{p}$.

Kaye, C. A., 1976, The geology and early history of the Boston area of Massachusetts, a bicentennial approach: U.S. Geological Survey Bulletin B-1476, 78 p.

1980, Bedrock geologic map of the Boston North, Boston South, and Newton quadrangles, Massachusetts: U.S. Geological Survey Miscellaneous Field-Studies Map MF-1241, scale 1:24,000, 2 sheets.

Knott, J. F., and Olimpio, J. C., 1986, Estimation of recharge rates to the sand and gravel aquifer using environmental tritium, Nantucket Island, Massachusetts: U.S. Geological Survey WaterSupply Paper 2297, 26 p.

Lindholm, G. F., 1980, Ground-water appraisal of sandplains in Benton, Sherburne, Stearns, and Wright Counties, Central Minnesota: U.S. Geological Survey Open-File Report 80-1285, 103 p.

McDonald, M. G., and Harbaugh, A. W., 1984, A modular three-dimensional finite-difference ground-water-flow model: U.S. Geological Survey Open-file Report 83-875, 528 p.

Massachusetts Department of Environmental Quality Engineering, 1976, Compilation of lakes, ponds, and reservoirs relative to the Massachusetts Lake Classification Program: Division of Water Pollution Control, $124 \mathrm{p}$.

1977, The Charles River, part C, water-quality analysis: Division of Water Pollution Control, $174 \mathrm{p}$.

1979, The Charles River, water-quality data, 1978: Division of Water Pollution, 74 p.

Morrissey, D. J., 1983, Hydrology of the Little Androscoggin River valley aquifer, Oxford County, Maine: U.S. Geological Survey WaterResources Investigations Report 83-4018, 55 p.

National Oceanic and Atmospheric Administration, 1984, Climatological data annual summary, New England, v. 96, n. 13, 36 p.

Nelson, A. E., 1974, Surficial geologic map of the Natick quadrangle, Middlesex and Norfolk Counties, Massachusetts: U.S. Geological Survey Geologic Quadrangle Map GQ-1151, scale 1:24,000, 1 sheet. 
Rasmussen, W. C., and Andreasen, G. E., 1959, Hydrologic budget of the Beaverdam Creek basin, Maryland: U.S. Geological Survey Water-Supply Paper 1472, 106 p.

Reeder, Harold O., 1972, Availability of ground water for irrigation from glacial outwash in the Perham area, Otter Tail County, Minnesota: U.S. Geological Survey Water-Supply Paper 2003, p. 25-32.

Reilly, T. E., Franke, O. L., and Bennett, G. D., 1987, The principle of superposition and its application in ground-water hydraulics: U.S. Geological Survey Techniques of Water Resources Investigations, book 3, chap. B6, 28 p.

Rorabaugh, M. T., 1956, Groundwater in Northeastern Louisville Kentucky, with reference to induced infiltration: U.S. Geological Survey Water-Supply Paper 1360-B, p. 101-169.

Theis, C. V., 1935, The relation between the lowering of the piezometric surface and the rate and duration of discharge of a well using groundwater storage: Transactions of the American Geophysical Union, v. 16, p. 519-524.

Thomas, M. P., 1966, Effect of glacial geology upon the time distribution of streamflow in eastern and southern Connecticut: U.S. Geological Survey Professional Paper 550-B, p. B209-B212.

U.S. Environmental Protection Agency, 1971, Charles River water-quality study: U.S. Environmental Protection Agency, Boston, Mass., 65 p.

U.S. Federal Water Pollution Administration, 1968, Chemical and physical aspects of water quality of the Charles River and Boston Harbor, Massachusetts: Technical Advisory and Investigations Branch Report, 9 p.

Volckman, R. P., 1975a, Surficial geologic map of the Holliston Quadrangle, Middlesex, Norfolk, and Worcester Counties, Massachusetts: U.S. Geological Survey Geologic Quadrangle Map, GQ-1217, scale 1:24,000.

1975b, Surficial geologic map of the Medfield Quadrangle, Norfolk and Middlesex Counties, Massachusetts: U.S. Geological Survey Geologic Quadrangle Map GQ-1218, scale 1:24,000, 1 sheet.
1977, Bedrock geologic map of the Holliston and Medfield quadrangle, Middlesex, Norfolk, and Worcester Counties: U.S. Geological Survey Miscellaneous Investigations Map I-1053, scale $1: 48,000,1$ sheet.

Walker, Eugene H., Caswell, William W., and Wandle, S. William, Jr., 1977, Hydrologic data of the Charles River basin, Massachusetts: U.S. Geological Survey Massachusetts Hydrologic-Data Report, no. 19, 53 p.

Walker, E. H., Wandle, S. W., Caswell, W. W., 1975, Hydrology and water resources of the Charles River Basin, Massachusetts: U.S. Geological Survey Hydrologic Investigations Atlas HA-554, scale 1:48,000, 2 sheets.

Wandle, S. W., Jr, 1984, Gazetteer of hydrologic characteristics of streams in Massachusetts--coastal river basins of the North Shore and Massachusetts Bay: U.S. Geological Survey WaterResources Investigations Report 84-4281, p. 39-40. 



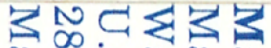

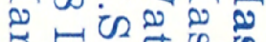

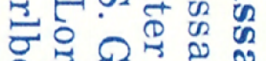

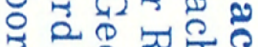

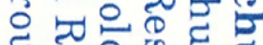

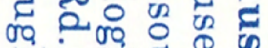

5 os

उE.

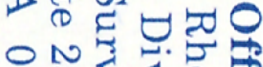

象

기요

क्ञ.

N

8

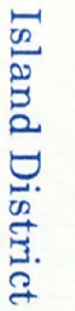

